\title{
The role of family firm specific resources in innovation: an integrative literature review and framework
}

\author{
Anne Heider ${ }^{1} \cdot$ Marcel Hülsbeck $^{1} \cdot$ Leopold von Schlenk-Barnsdorf $^{1}$
}

Received: 1 December 2020 / Accepted: 23 December 2021 / Published online: 24 January 2022

(c) The Author(s) 2022

\begin{abstract}
Family firms are the prevalent form of entrepreneurial organizations worldwide. While even long-lasting and successful family firms are said to invest less in innovation, their innovation output varies according to their heterogeneity often matching or even exceeding the output of other incumbent firms. These contradictory results have confused entrepreneurship and innovation researchers alike. Based on an integrative literature review we develop a conceptual framework to explain the role of family firm specific resources for innovation. Our analysis of 48 peer-reviewed empirical articles drawn from a body of 466 published empirical papers shows how our integrative perspective helps to solve these existing contradictions. We argue that higher investments into these family firm specific resources trigger a virtuous circle in family firm innovation.
\end{abstract}

Keywords Entrepreneurial firms · Family firm · Innovation · Family firm resources · Conceptual framework

JEL Classification $\mathrm{L} 10 \cdot \mathrm{L} 26 \cdot \mathrm{O} 30$

\section{Introduction}

Research interest in family firm innovation has flourished in the last decade (Hu and Hughes 2020; Calabrò et al. 2019; Filser et al. 2016; Padilla-Meléndez 2015; De Massis et al. 2013; Duran et al. 2016), highlighting idiosyncratic traits and

Anne Heider

Anne.Heider@uni-wh.de

Marcel Hülsbeck

Marcel.Huelsbeck@uni-wh.de

Leopold von Schlenk-Barnsdorf

Leopold.vonschlenk-barnsdorf@uni-wh.de

1 Witten Institute for Family Business, Witten/Herdecke University, Alfred-Herrhausen-Str. 50, 58448 Witten, Germany 
generating promising avenues of inquiry to analyze this phenomenon deeper (Chrisman et al. 2015a, b; De Massis et al. 2013; Kraiczy and Hack 2016; Duran et al. 2016). Innovation is essential for family firms to remain competitive and to ensure survival in an increasingly dynamic environment (Johnson et al. 2008). There are however strong theoretical reasons to believe that family firms may encounter greater difficulties in responding to innovation (König et al. 2013). As traditional or even conservative organizations unwilling to break away from proven ways of doing business in addition to their resource dependence, inertia and rigidity, family firms are further constrained by generational transition, emotional ties, and the pursuit of nonfinancial goals (Kotlar and De Massis 2013; Kotlar et al. 2018), which together impact how family firms manage innovation (König et al. 2013; De Massis et al. 2016a, b). Nevertheless, some family firms are amongst the most innovative firms in the world (De Massis et al. 2013, 2017, 2018; Urbinati et al. 2017), and their long-term orientation acts as a stimulus to innovation (Diaz-Moriana et al. 2018). Scholars argue that family firms are associated with lower innovation inputs (e.g., R\&D investments), than their nonfamily counterparts (De Massis et al. 2013; Calabrò et al. 2019), at the same time other studies show that family firms are associated with relatively high innovation outputs (e.g., new patents or products), and high levels of innovation (De Massis et al. 2013; Urbinati et al. 2017) at the same time. Consequently, there is a dilemma as studies find family firms to be at the same time better and worse equipped to handle this innovative pressure in comparison with non-family firms. The heterogeneity of family firms' ability to convert limited innovation inputs into outputs, is still poorly understood (Chrisman et al. 2013; De Massis et al. 2015). So far, several literature reviews (De Massis et al. 2013; Duran et al. 2016; Calabrò et al. 2019; Hu and Hughes 2020) have addressed innovation in family firms. De Massis et al. (2013) show what is available and develop differentiated questions and future directions in this regard. Based on a meta-analysis Duran et al. (2016) analyze that family firms invest significantly less in innovation than non-family firms do, their innovation output, ceteris paribus, is higher. Calabrò et al. (2019) provide a state of the art of the family firm innovation literature. They highlight the need for more contextualized understanding of innovation in family firms. $\mathrm{Hu}$ and Hughes (2020) categorize the existing studies into four prevelant theoretical approaches and derive key research questions for the field. All of these syntheses of the field are unable to answer the questions raised above. They lack a conceptual framework that can explain the peculiarities of innovation behaviour in family firms due to the specifics of family firms. In this paper, we use the established model of family specific resources as a base for developing a conceptual framework to better explain family firm innovation.

Family firms cultivate unique resource bundles (Habbershon and Williams 1999; Dyer 2003; Zahra et al. 2004; Zellweger 2007), which can be a source of innovation (Zahra et al. 2004; Eddleston et al. 2008; Spriggs et al. 2013; Carnes and Ireland 2013; Bammens et al. 2015). According to Sirmon and Hitt (2003) family firms are associated with unique human capital (i.e. knowledge, skills and capabilities), which is generally considered as their most important resource. Moreover, they are associated with unique social capital, which is essential to gain access to other forms of intellectual, human or financial capital (Sirmon and Hitt 2003, Sanchez-Ruiz et al. 
2019, Dawson 2012, Danes et al. 2009). Human capital includes the knowledge, skills and abilities in the family firm (Carney 2005, Danes et al. 2008, 2009; Dawson 2012; Sirmon and Hitt 2003). Human capital of a family firm is complicated by the overlap of business and family, as family members often work in the firm. They simultaneously participate in both businesses and family relationships in their professional lives. The duality of these relationships increases their complexity and creates an unique context for human capital compared to nonfamily firms. Moreover, family firms are chracterized by long-lasting employment contracts and employee retention. These long-term employees acquire highly firm specific human capital and tacit knowledge that builds up over the years and contributes to family firm innovation in a unique way. (Danes et al. 2008; Rondi et al. 2021; Sirmon and Hitt 2003). Social capital is best described as the bundle of resources that can be acquired or utilized through networks with external stakeholders. These resources embedded in social relationships are crucial for family firms' innovation (Sanchez-Famoso et al. 2019; Sanchez-Ruiz et al. 2019). Social capital in family firms is enhanced by strong ties, more often than not built up over generations, that exist among family members and stakeholders providing a system of connections for mutual advice and communication, which are elements necessary to work towards innovation. In addition, family firms are further characterized by their unique financial capital, which may limit their sources of external financial capital due to their avoidance of sharing equity with non-family members. Recently, survivability capital is unique to family firms and refers to the bundle of personal resources that family members are willing to loan, contribute, or share in order to support their family's business (Sirmon and Hitt 2003). By examining these peculiarities of family firms, we also offer deeper insights into the largely unopened black box of family firm heterogeneity on the basis of their unique resources bundles (Chua et al. 2012). This very heterogeneity can further be considered as a critical factor for a better understanding of innovation in the family business context (Urbinati et al. 2017). However, there is still a research gap in the existing literature being unable to explain the question of how resources are bundled. We use the approach of an integrative literature review to create new insights about this topic by critically reviewing the published empirical literature on family firm innovation (Torraco 2005; Snyder 2019). To this end, we look in detail at what the individual family specific resources mean for innovation management and examine in particular the connection and interfaces between individual resources. By analyzing the results of the specific resources on innovation based on our integrative perspective, we make a theoretical contribution by following the trend of current research to go beyond the literature review to a theory-building goal (Hoon and Baluch 2020; Post et al. 2020). We provide a conceptual framework as a basis for a more nuanced understanding of the core mechanisms underlying application responses and the established and proposed relationships between variables.

The remainder of the article is structured as follows. The next section introduduces the state of the art of family firm innovation research along major topics within this research stream. Next, we describe the idea of family firm specific resources as a theoretical base for our analysis of the literature. We provide a threecircle model as a basis for opening the black box and investigating the interdependencies of the resources in detail to examine what importance specific resources do 
have for innovation in family firms. The methodology section gives detailed insights into the search and selection strategy of our integrative review of the literature. The fifth section of the paper analyzes the current literature based on the previously established model of family firm specific resources and resource bundles. Here, we formulate differentiated propositions that not only capture the current knowledge but can also be used to guide future research in the field. In the final section we then conclude and discuss our findings from the analysis and give advice for a future research agenda.

\section{Major topics in family firm innovation research}

The first major topic in the literature on family firm innovation deals with the determinants or drivers of innovation, also referred to as innovation inputs, such as investments in R\&D and thus R\&D intensity (De Massis et al. 2013; Urbinati et al. 2017). R\&D expenditures are necessary for innovation (Block 2012; Cucculelli and Bettinelli 2015) as they serve as a key factor to gain and sustain a competitive advantage and increase firm performance (Kotlar et al. 2014). Several studies observe a negative relationship between family involvement in a firm and its level of R\&D investments, due to conservatism and risk aversion (Chen and Hsu 2009; Anderson et al. 2010; Nieto et al. 2015, Broekaert et al. 2016), the limited risk propensity of controlling shareholders (Munari et al. 2010), the various identities of family owners (Block et al. 2011), inner family conflicts (Block 2012), family firms' limited resources (Muñoz-Bullón and Sanchez-Bueno 2011; Nieto et al. 2015) and loss aversion with regard to their non-financial goals (Gómez-Mejia et al. 2007, 2014). However, scholars observe that R\&D investments in family firms tend to increase, when their firm performance falls below aspiration levels and consequently family as well as economic goals increasingly overlap (Block et al. 2013; Chrisman and Patel 2012; Patel and Chrisman 2014; Sciascia et al. 2015). The literature also finds a negative relationship between family governance and R\&D intensity, due to an overlap between family wealth and firm equity (Sciascia et al. 2015), family influence through ownership, management and governance, which leads to resource scarcity (Matzler et al. 2015) as well as family control (Schmid et al. 2014). A contrasting finding, however, argues that family firms have a particularly high innovation output-higher quality of innovation in terms of number of patents and citationsas their ability to capitalize on their innovations is particularly high (Matzler et al. 2015).

Technological innovation (De Massis et al. 2013) is another valuable outcome of value creating innovation activities. On the one hand, family firms are considered as particularly capable of technological innovation due to their flexible structures and decision-making processes (Craig and Dibrell 2006). On the other hand, they are less likely to turn to external sources of innovation and technological collaboration than their non-family counterparts (Nieto et al. 2015). Recent studies on German Mittelstand firms - many of which are family firms - confirm that these are particularly innovative due to specific characteristics (De Massis et al. 2018; Heider et al. 2021). 
In addition to the various sources and types of innovation, there is further differentiation with respect to the level of innovation (i.e. incremental, progressive or radical) and its magnitude (i.e. exploitative or explorative) (Sharma and Salvato 2011). Family firms are particularly well-equipped for exploiting opportunities in domains close to their current operations through the pursuit of incremental and/or progressive innovation, due to their long-term orientation as well as their unique human and social capital (Patel and Fiet 2011; Sharma and Salvato 2011; Hiebl 2015). More recent findings confirm that family firms are more likely to achieve incremental than radical innovations (Nieto et al. 2015) and perform particularly well in the domain of exploitative innovations (Bammens et al. 2015). The exploration of new opportunities (e.g. new markets and products) is typically followed by radical innovations and becomes essential in dynamic business environments (Bergfeld and Weber 2011), but also when existing markets or product lines saturate (Sharma and Salvato 2011). In order to ensure long-term survival and performance advantages, however, family firms need to engage in both, the pursuit of exploration and exploitation (Sharma and Salvato 2011), an ability referred to as organizational ambidexterity (March 1991; Tushman and O'Reilly 1996; O'Reilly and Tushman 2004). Salvato and Melin (2008) investigate the antecedents of long-term innovation in family firms on the basis of their financial outcomes and strategic sustainability and investigate their abilities to dynamically recombine sources of competitive advantage. They find that family firms systematically create value over generations through their ability to renew and reshape their social interactions within and outside the controlling family. Also, they show that organizational ambidexterity is important for family firms to create financial value and competitive sustainability over generations, by performing continuous improvement of their original competencies and innovation through exploitation, punctuated by more or less radical strategic innovations through exploration (Salvato and Melin 2008). In a similar vein, Bergfeld and Weber (2011) show that successful family firms do not only follow a clear long-term strategy of constantly addressing new opportunities (e.g. new market and technologies), but are also considered as ambidextrous organizations. They seek for both, incremental innovation in daily operations and radical innovation and/or corporate renewal in order to assure their "future-proofness". The former is mostly executed by external managers, while the responsibility for the latter lies in the family (Bergfeld and Weber 2011).

In summary, family firms are associated with a tendency to low innovation inputs (e.g. R\&D expenditures), but high innovation outputs (e.g. new patents or products) (Duran et al. 2016). Especially, in contrast to non-family firms, firms with family involvement innovate more efficiently than do non-family firms (Lodh et al. 2014; Matzler et al. 2015). Family firms require consistency between their innovation decisions and approaches as well as their family firm specific characteristics in order to take full advantage of their innovation potential (De Massis et al. 2015). However, if the innovation process is not institutionalized within the family and the business by means of family and corporate 
governance, their special ability — on the basis of their unique family assetscan atrophy and stifle innovation performance over time (Bennedsen and Foss 2015).

\section{Theoretical framework: family firm specific resources}

The resource based view (RBV) assumes that differences in firm performance, the creation of competitive advantages and entrepreneurial outcomes, such as innovation are largely attributable to resources and capabilities (Penrose 1959; Wernerfelt 1984; Barney 1991). Due to the continous involvement of the family in the business, family firms develop unique resource bundles (Habbershon and Williams 1999; Dyer 2003; Zahra et al. 2004; Zellweger 2007), which can be a source of competitive advantage (Cabrera-Suárez et al. 2001) and innovation (Zahra et al. 2004; Eddleston et al. 2008; Spriggs et al. 2013; Carnes and Ireland 2013; Bammens et al. 2015). On the downside, like all incumbent firms (Christensen 2013), family firms vary in their ability to respond to disruptive threats by their capabilities to allocate and commit resources (König et al. 2013; Weimann et al. 2020), because of family firms' dependence on their specific resource bundles producing lock-ins, inflexibility (Zahra et al. 2004), and rigidity (Roessl et al. 2010).

According to Simon and Hitt (2003) (Sirmon et al. 2007, 2011), the special nature of family businesses beyond their governance structure can be described by the existence of the following specific resources: human capital, social capital, patient financial capital, and survivability capital.

In more detail, family firms are associated with unique human capital (i.e. knowledge, skills and capabilities), which is generally considered as their most important resource (Sirmon and Hitt 2003). A major characteristic of their human capital is the typical long-term orientation of family firms (Dyer 2003; Zellweger 2007). Due to their long-term orientation and more specifically their long employee, management and leadership tenures (Patel and Fiet 2011; Bammens et al. 2015; Röd 2016), family firms are further associated with unique intellectual human capital, which refers to their explicit and deep firm specific tacit knowledge (Sirmon and Hitt 2003; Rothaermel and Hess 2007). Scholars find that family firms devote a substantial amount of their human capital to innovation (Llach and Nordqvist 2010) and in line with their long-term orientation, it does not only affect their innovativeness, but especially their ability to respond to disruptive threats and thus their rate of disruptive innovation. (De Massis et al. 2013). Consequently, family firms may have an increased ability to pursue innovation, as such cannot only take particularly long to produce tangible returns (Chesbrough 2007; Foss and Saebi 2017; Teece and Linden 2017), but is highly dependent on the top management, its long-term commitment and is mostly performed under a top-down approach so that necessary resources are provided quickly and without bureaucracy (Chesbrough 2010; Bucherer et al. 2012) (Fig. 1).

Social capital summarizes the resources resulting from the relationships between organizational members and with external stakeholders (Adler and Kwon 


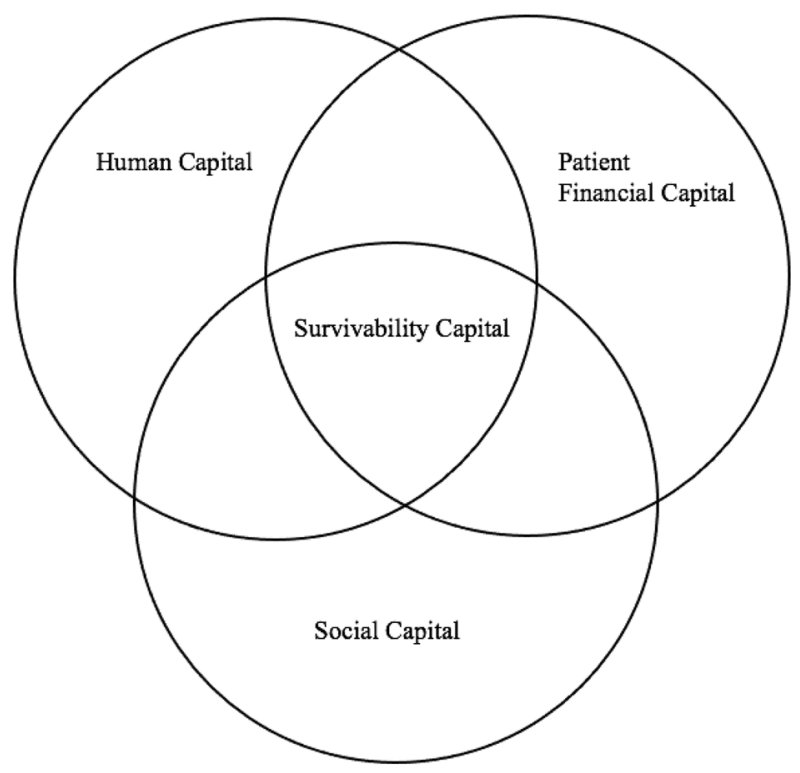

Fig. 1 Theoretical framework: family firm specific resources

2002; Hoffmann et al. 2006; Llach and Nordqvist 2010). Family firms are associated with unique social capital, which is essential to gain access to other forms of intellectual, human or financial capital (Sirmon and Hitt 2003). Family firms typically have a superior ability to nurture and develop prosperous, long-standing relationships with their stakeholders and also to establish more cooperation, both formally and informally, which can further increase their innovativeness (Miller et al. 2015). Cooperation is considered as an important innovation input (Llach and Nordqvist 2010) affecting the tendency to rely more on the contribution of external sources of knowledge during the innovation process (De Massis et al. 2013), which becomes particularly important for innovation, which largely builds on collaborations with external partners (Eppler et al. 2011; Zott et al. 2011).

Family firms are further characterized by their unique patient financial capital, which may-in the first place-limit their sources of external financial capital due to their avoidance of sharing equity with non-family members (Sirmon and Hitt 2003). But, due to their unique patient capital, family firms are also exempted from the pressure for short-term paybacks in the management of innovation (Dunn 1996; De Massis et al. 2013), which non-family firms are usually imposed on by external investors and capital markets (Gómez-Mejía et al. 2001; De Massis et al. 2013). This is particularly beneficial for the management innovation projects, which usually take a long time - sometimes even years or decades - until they produce tangible returns given their risks and lags in revenue generation (Foss and Saebi 2017; Teece and Linden 2017; Chesbrough 2010). Survivability capital is unique to family firms and according to Sirmon and Hitt (2003) describes to the bundling and overlapping of the individual family-specific resources. 
Ultimatey, recource based theory allows for a deeper analysis of the heterogeneity of family firms since their unique resources and capabilities commonly reside to varying degrees in family firms and thus largely account for their great heterogeneity (Habbershon and Williams 1999; Sirmon and Hitt 2003). In dynamic business environments and especially in times of disruptive change, however, resources alone are no longer sufficient to explain innovation success (Eisenhardt and Martin 2000; Ray et al. 2004). Therefore, it is all the more important to identify and bundle one's internal resources so that bundling them becomes a competitive advantage. We assume that the competitive advantage is created by bundling the individual family specific resources. Obviously, the bundling of resources can strengthen each other, which then leads to more innovation. However, the effect of the resource bundles can also deteriorate, which leads to less innovation.

\section{Methodology}

The aim of this integrative literature review is to develop a conceptual model (Torraco 2005; Booth et al. 2012, p. 40; Snyder 2019) of how family firm specific resources and resource bundles are able to explain the heterogeneity in family firm innovation. Accordingly, the selection of studies integrated in this review is based on a number of a priori considerations. First of all, our enquiry is restricted to peerreviewed academic journals in English language which empirically investigate family firm specific resources - or proxies for these resources. The rationale behind these rather restricted inclusion criteria is the attempt to derive an evidence-based model rather than produce a canonical and all encompassing overview of possible influencing factors (Webster and Watson 2002; Tranfield et al. 2003).

To identify the relevant studies, we first conducted a systematic search by using the leading scientific research database EBSCO Business Source Complete. In more detail, we conducted a title and abstract search by using the key terms "family business" or "family firm" and combined them (AND) with the term "innovat*" to capture variations of the words innovation(s), innovating, innnovativeness, etc. This search was restricted to peer-reviewed articles only. In parallel, we conducted a title search combining the search phrases " "family firm' AND innovation" as well as “'family business' AND innovation" on Google Scholar utilizing the Publish or Perish software package (Harzing 2007). This search was not a priori restricted to peerreviewed articles which enabled us to cast a wider net and make sure that also very recently accepted papers are included within the search. As a third step, we conducted a comparable search pattern as in the first step utilizing the JSTOR repository. This last search was more of a robustness check and-as we expected-yielded no additional results. All three research steps led to 926 data records.

The raw data were cleaned in a three-step procedure. First, all non-English articles (Chinese, Czech, French, German, Greek, Polish, Portuguese, Russian, Spanish, Turkish) were removed. Second, by filtering the data for blanks in the Journal Name field of the database and than manually looking up the Publisher or publication context, 177 records of non peer-reviewed articles were identified. The overwhelming majority of these stem from the Google Scholar search results, as it is not possible 
to filter for peer reviewed journals only. Nevertheless, a few of these records came from the other searches and had obviously slipped past the search filters of said databases. In a last step, we removed the remaining duplicates in the database. The order of this three-step process is necessary as it is possible that a pre-print version as well as a published version of an article is listed in the search results. Only by manually checking the publication context beforehand one can ensure that the published version is kept when duplicates are removed through an automated procedure (we used the duplicate removal feature in MS Excel). The data cleaning process left us with 466 unique peer reviewed articles based on our search terms above.

The most demanding task of the paper selection process was to decide which papers are within the scope or beyond the scope of our investigation. In a first step, all paper titles and abstracts were read regarding their relevance for the topic at hand. In this first step, 342 articles were excluded. Common reasons for exclusion were: (a) the lack of empirical primary data in the articles (e.g. editorials, pointcounterpoints, commentaries, and opinion pieces), (b) papers that dealt with related fields but did not define or operationalize family firms (e.g. SMEs, New Technology Based Firms, Start-Ups, etc.), (c) papers that contained the word "family" in title or abstract without referring to family firms (e.g. in female entrepreneurship literature the word "family" is used quite often, similarly "product families" are often referenced in marketing), (d) articles that dealt with other family firm topics (mainly internationalization, sustainabilitiy, CSR, family business groups, and succession) that refer to innovation within the abstract. This left us with 120 articles.

The remaining 120 articles were completely read and judged based on the questions whether the conceptually and empirically adressed our research interest as a main topic within a generalizable logic (Bakker 2010; David and Han 2004). Of these, 28 papers were excluded as they only addressed corporate governance research variables without referring to any kind of resource base of the firm, 23 were excluded as they conceptually referred to family firm specific resources but did not include any (even coarse) proxies in their empirical part. 17 additional papers turned out to be literature reviews or purely conceptual, these papers were not included in the analysis but have been used and referenced in the previous sections of this paper. Additional five papers only used innovation as a moderator, while three more papers looked at very specific innovation contexts (e.g. green or eco-innovations) that are not driven by the general innovation literature. These papers were excluded as these specific context did not allow to draw relevant conclusions for the research at hand. All in all, we were able to include 48 peer reviewed papers in this review. An overview of our search, cleaning, and exclusion, and inclusion procedure is displayed in Table 1. These 48 papers were coded with regard to the family firm specific resources or resource bundles they addressed and are analyzed in the next section of the paper (see Table 2). 


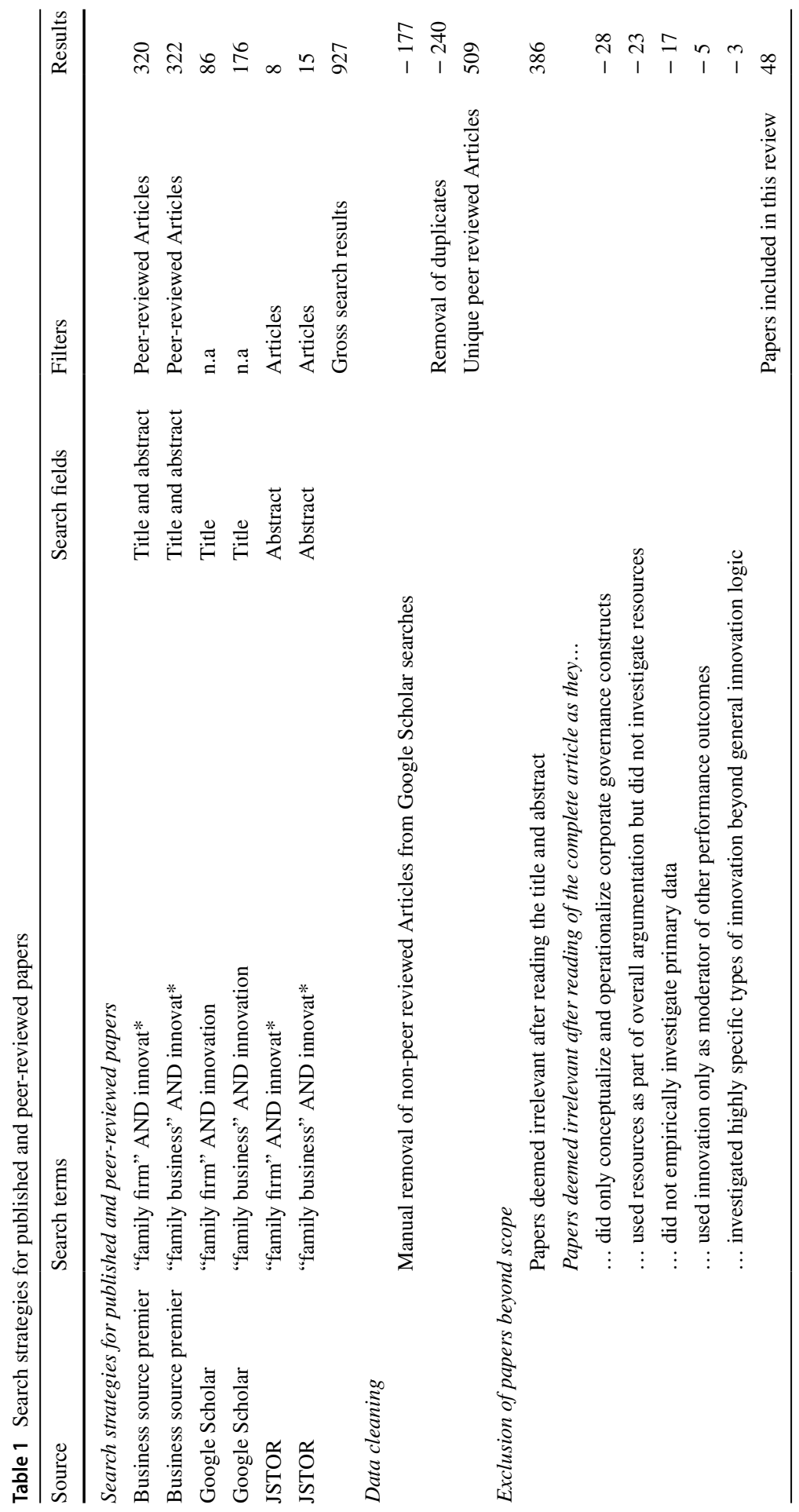




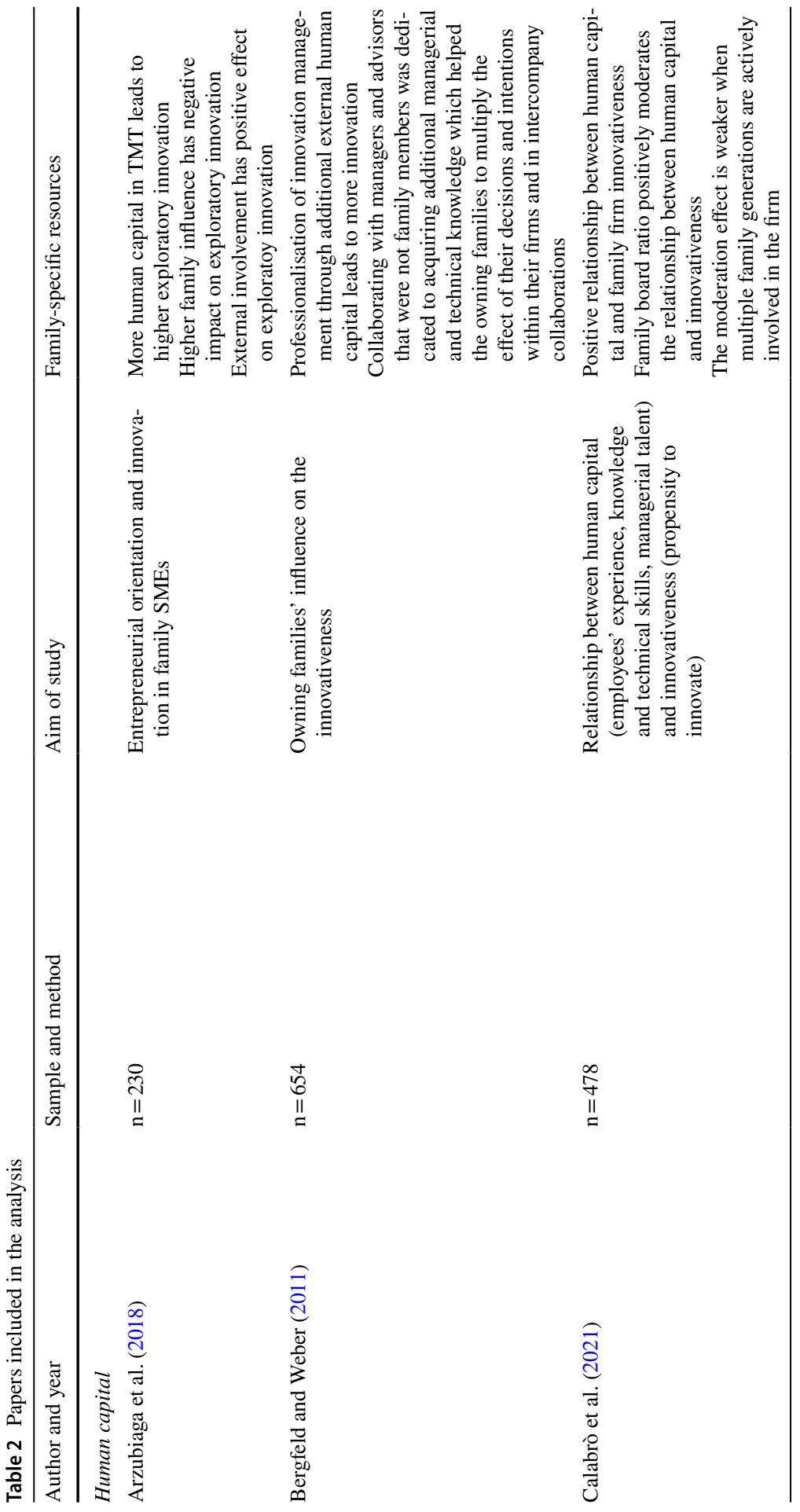




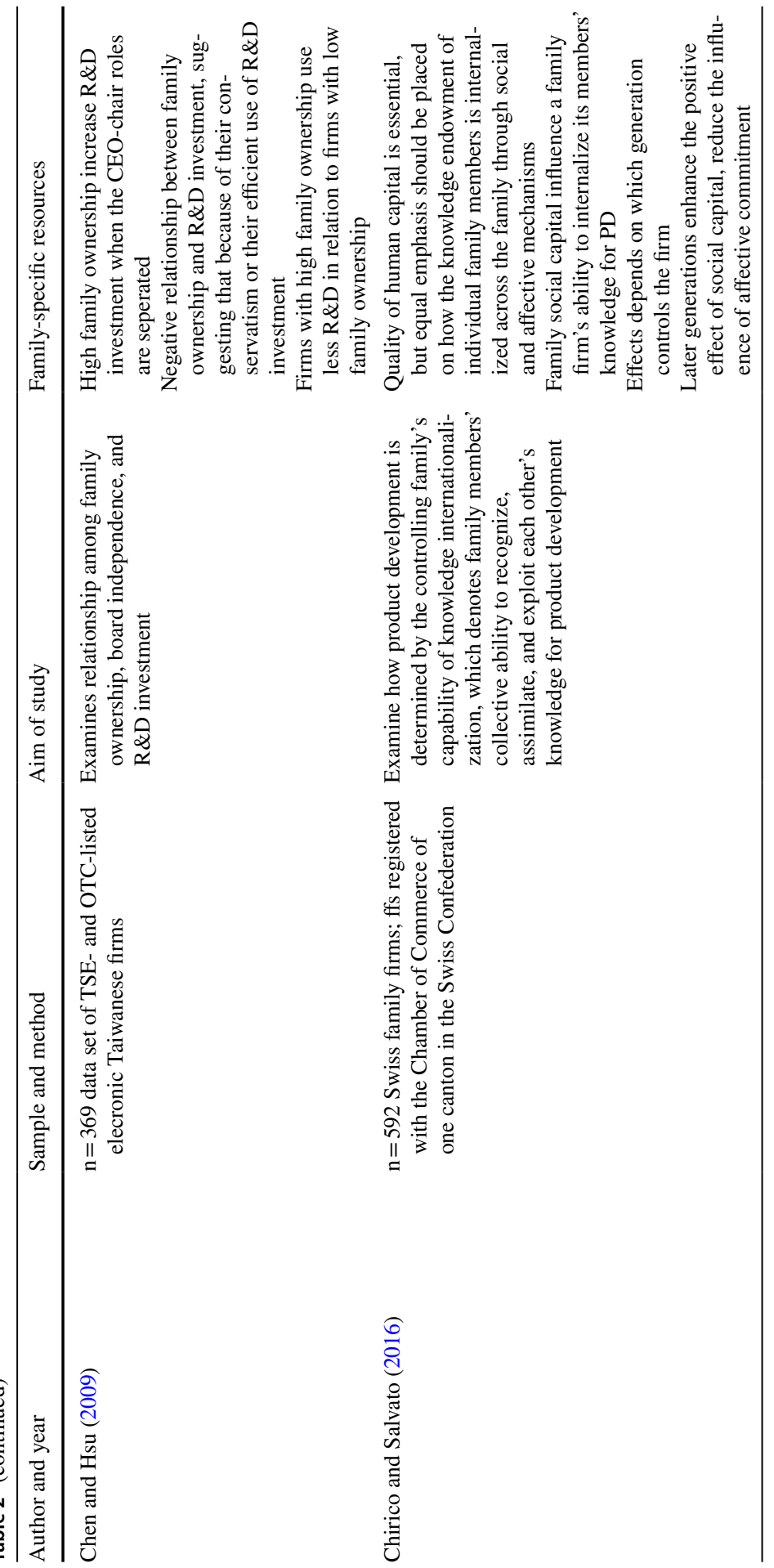




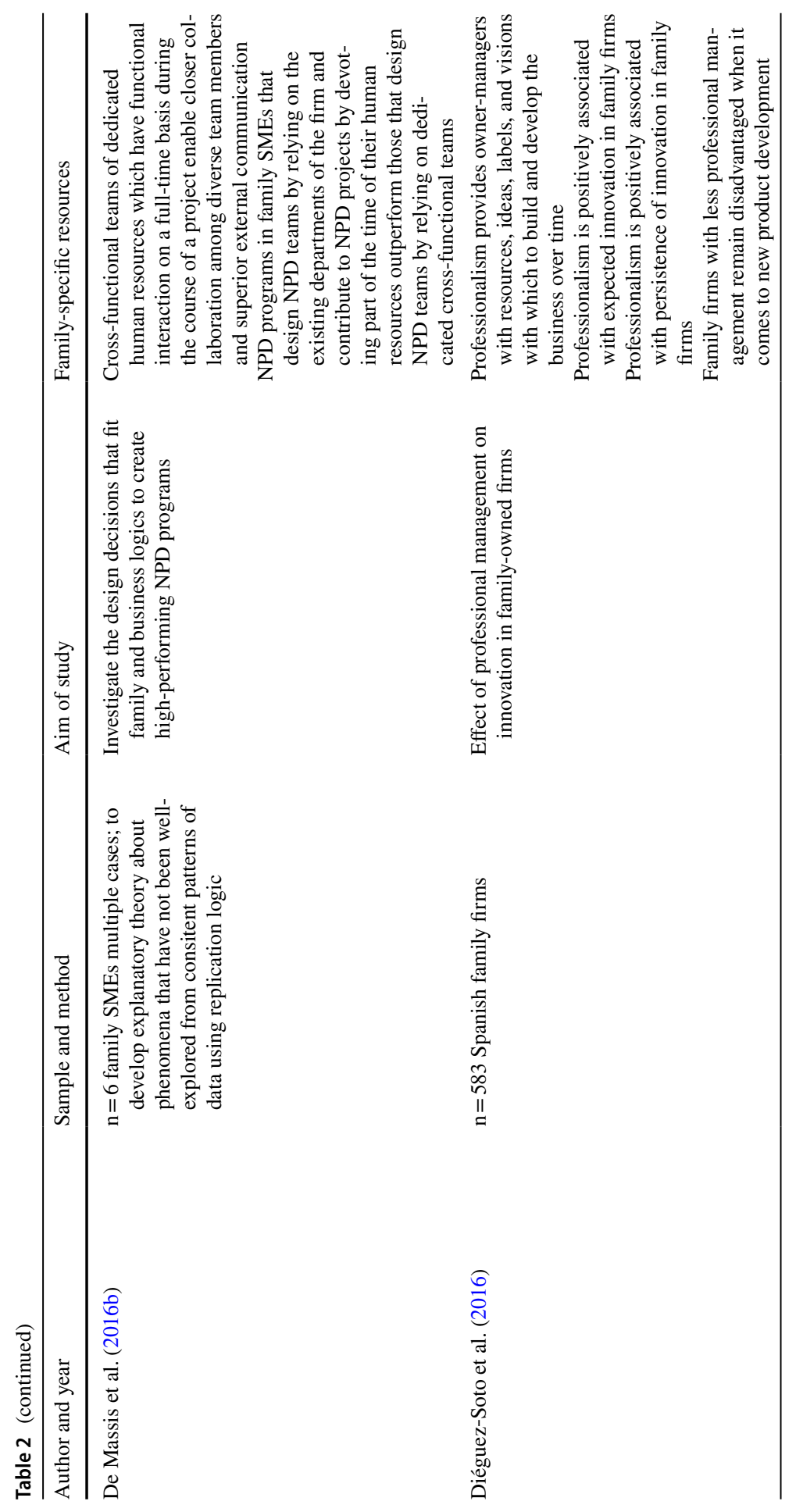




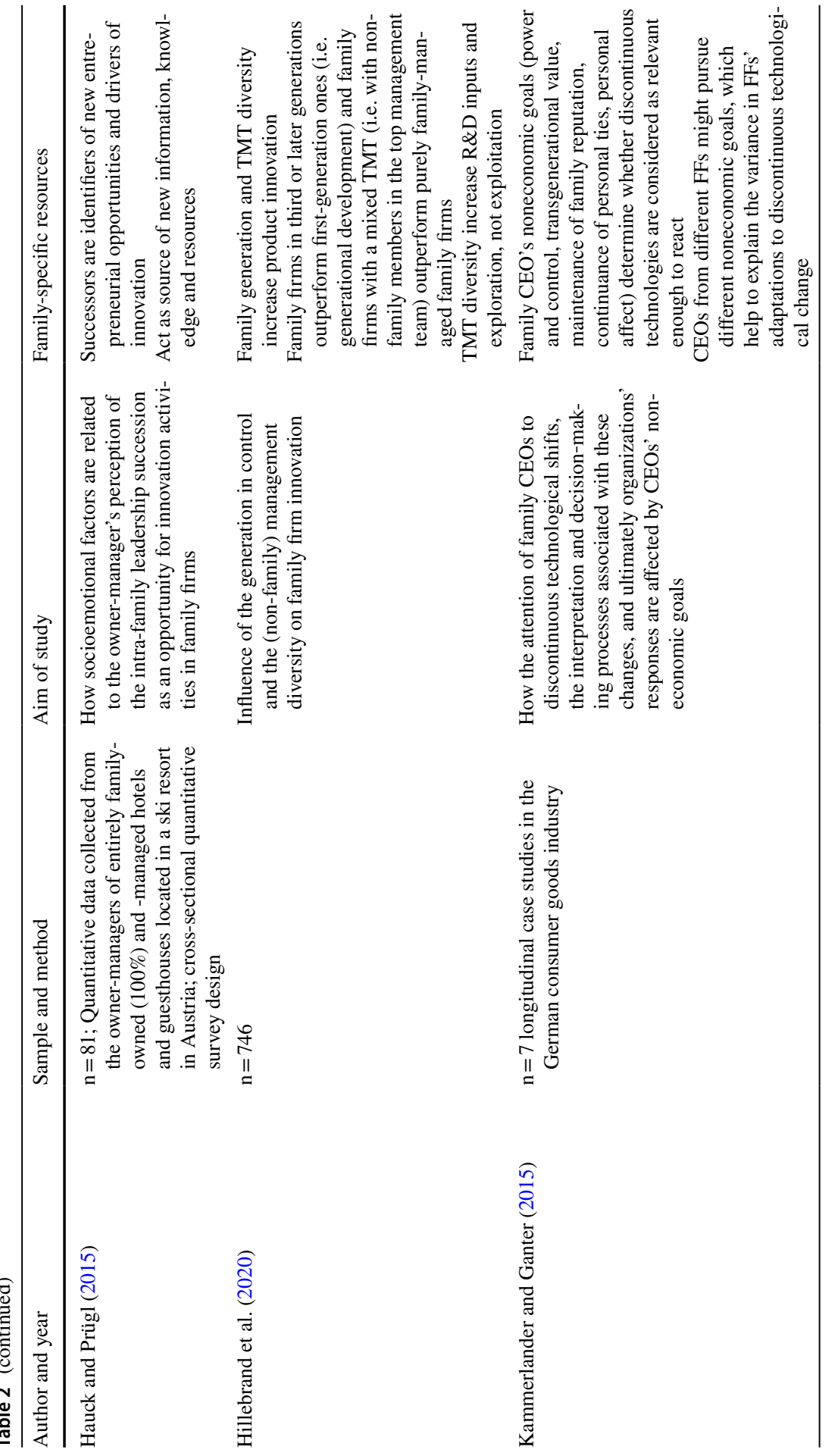




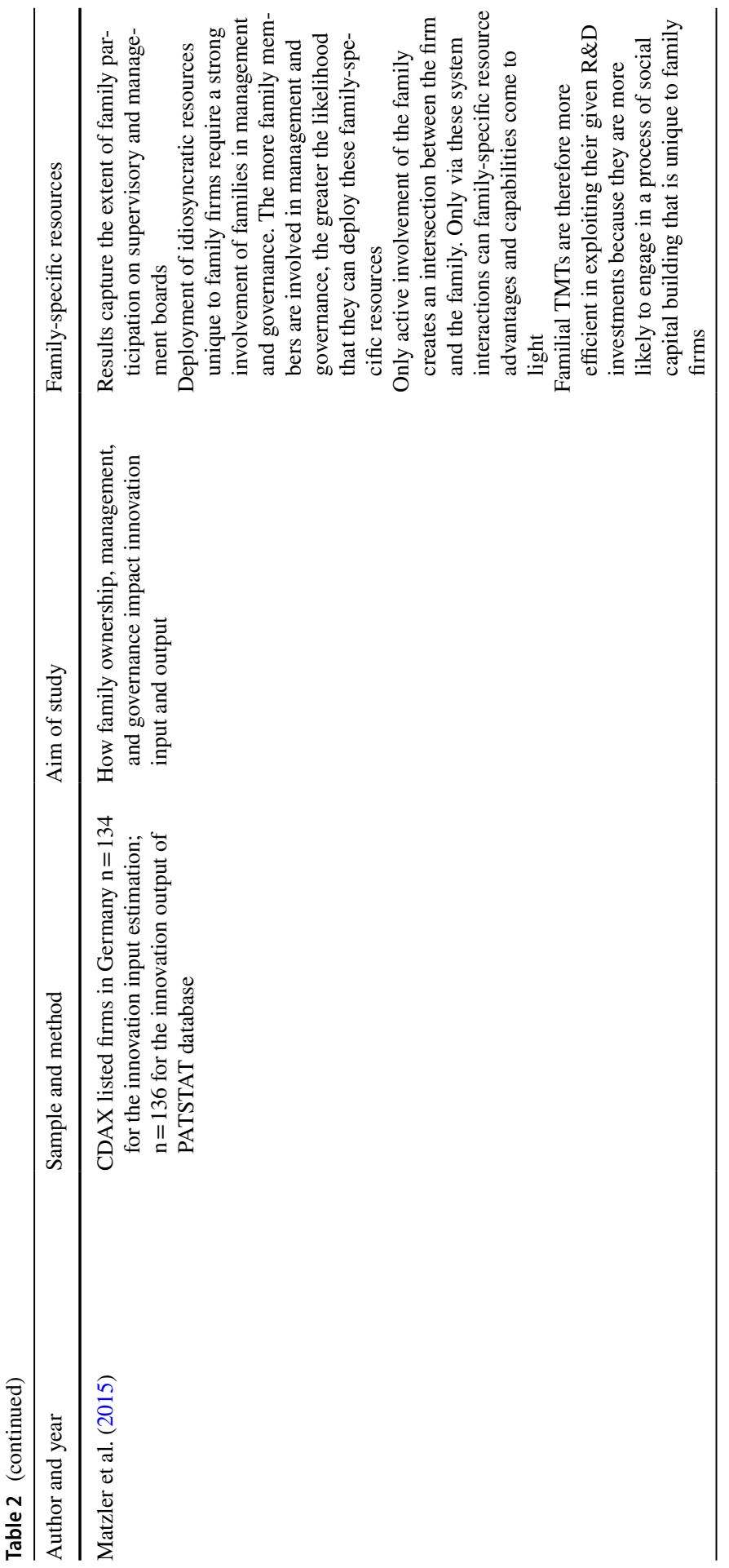




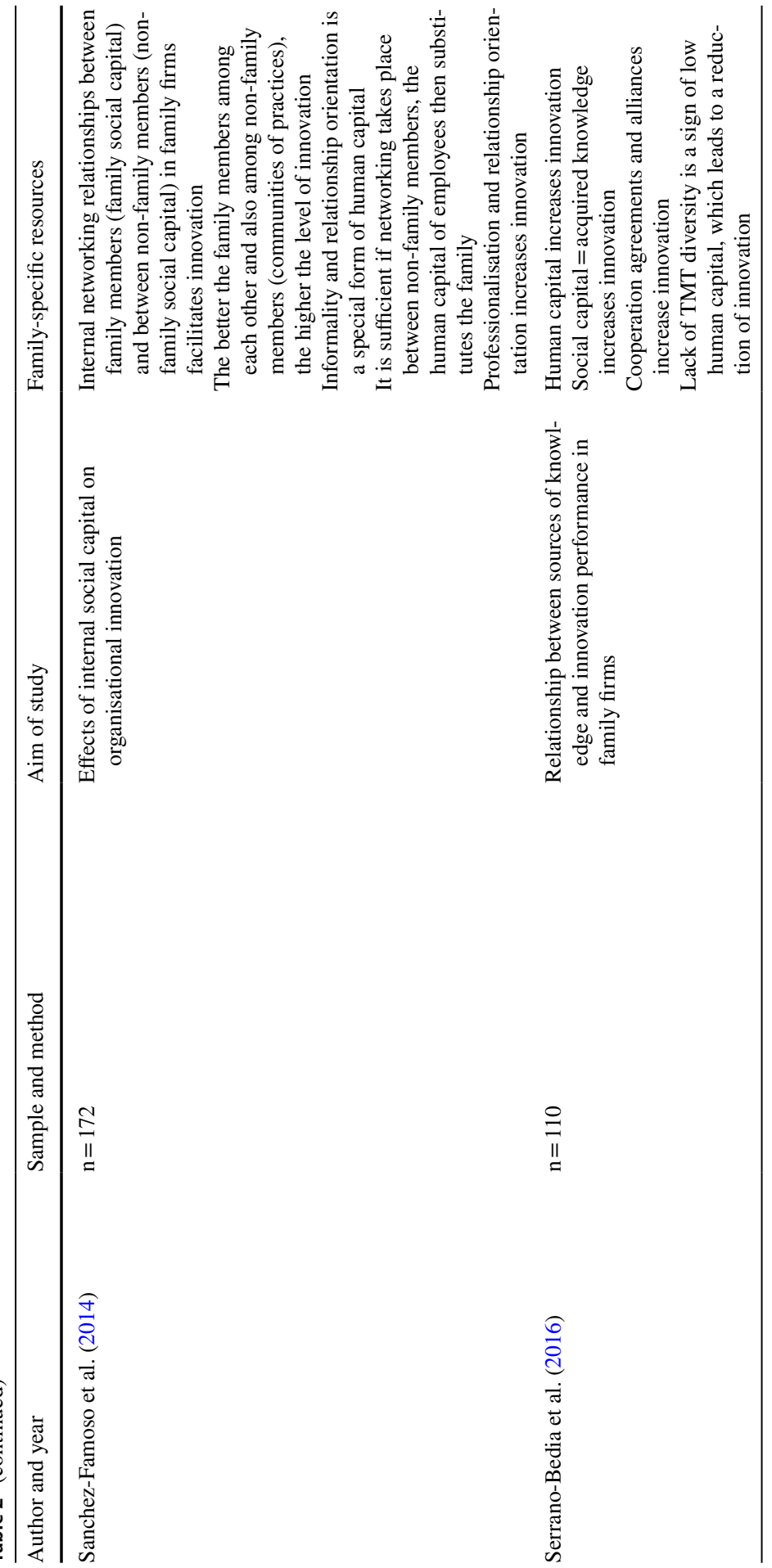




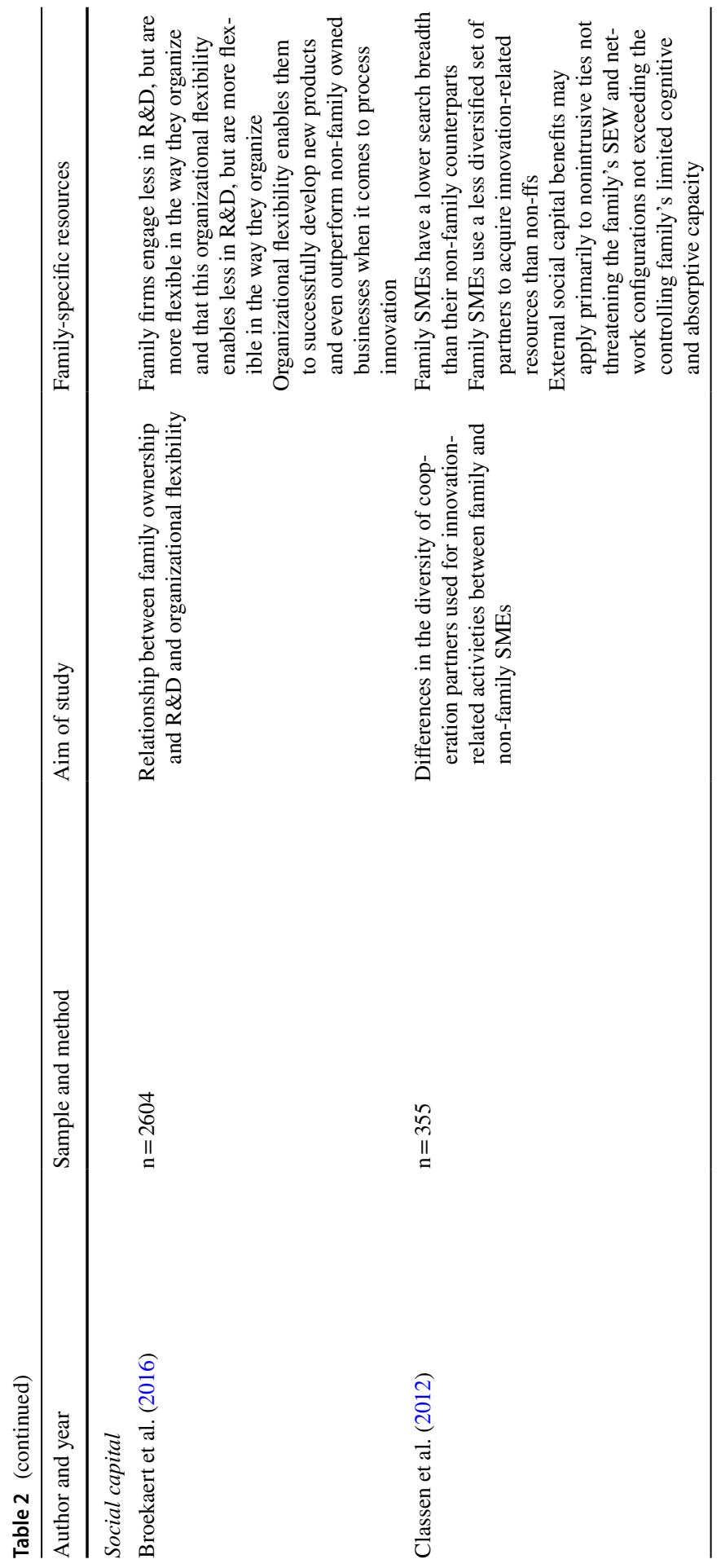




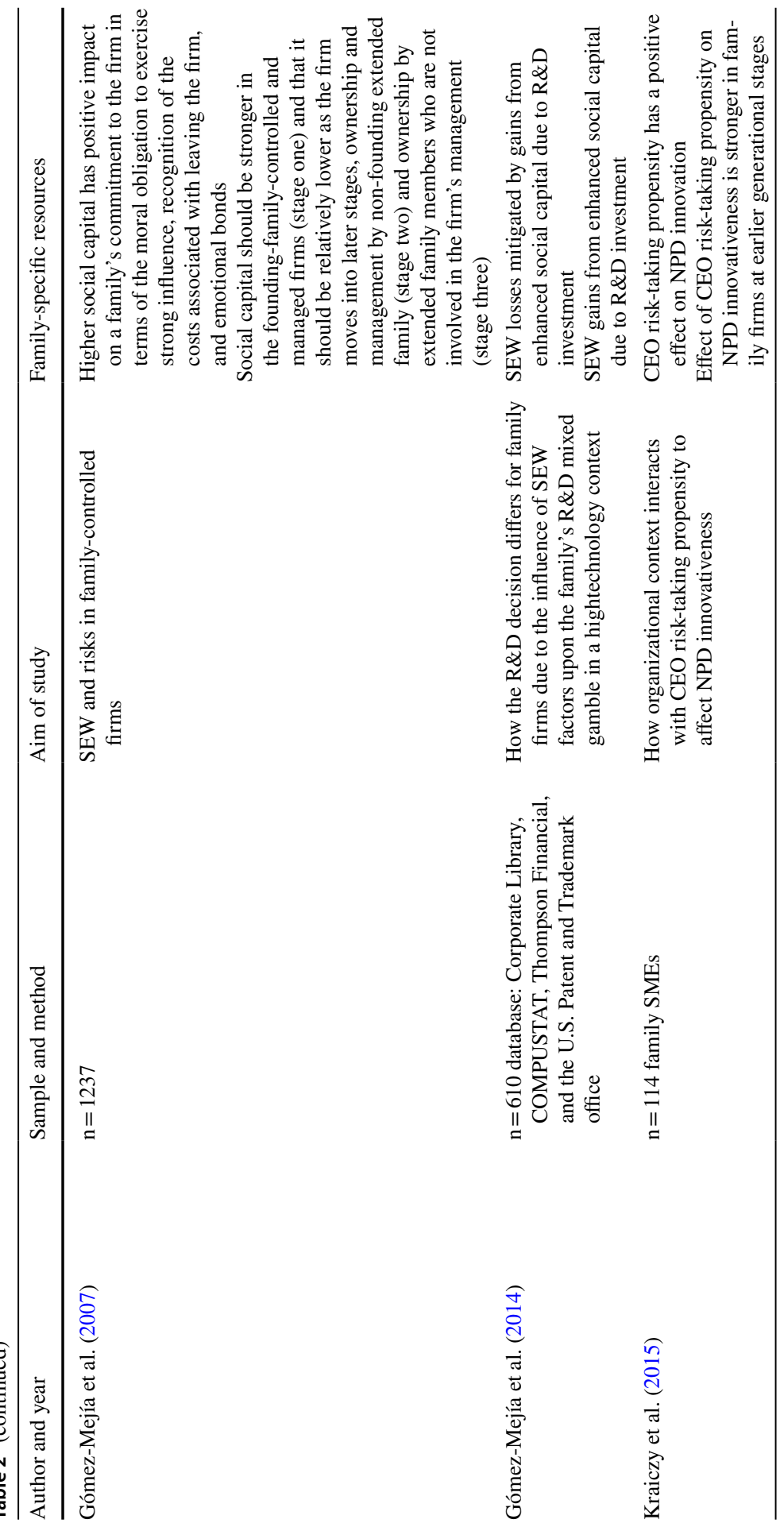




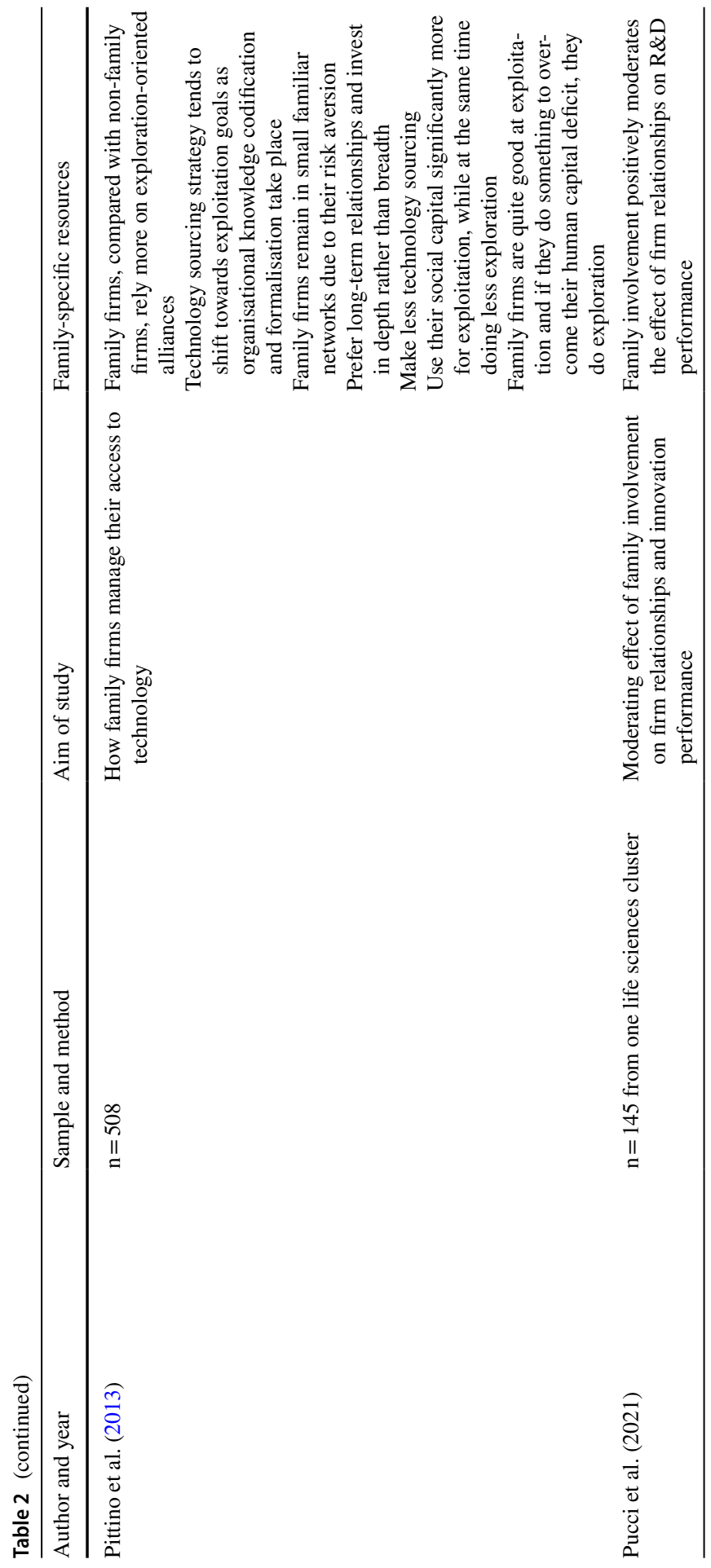




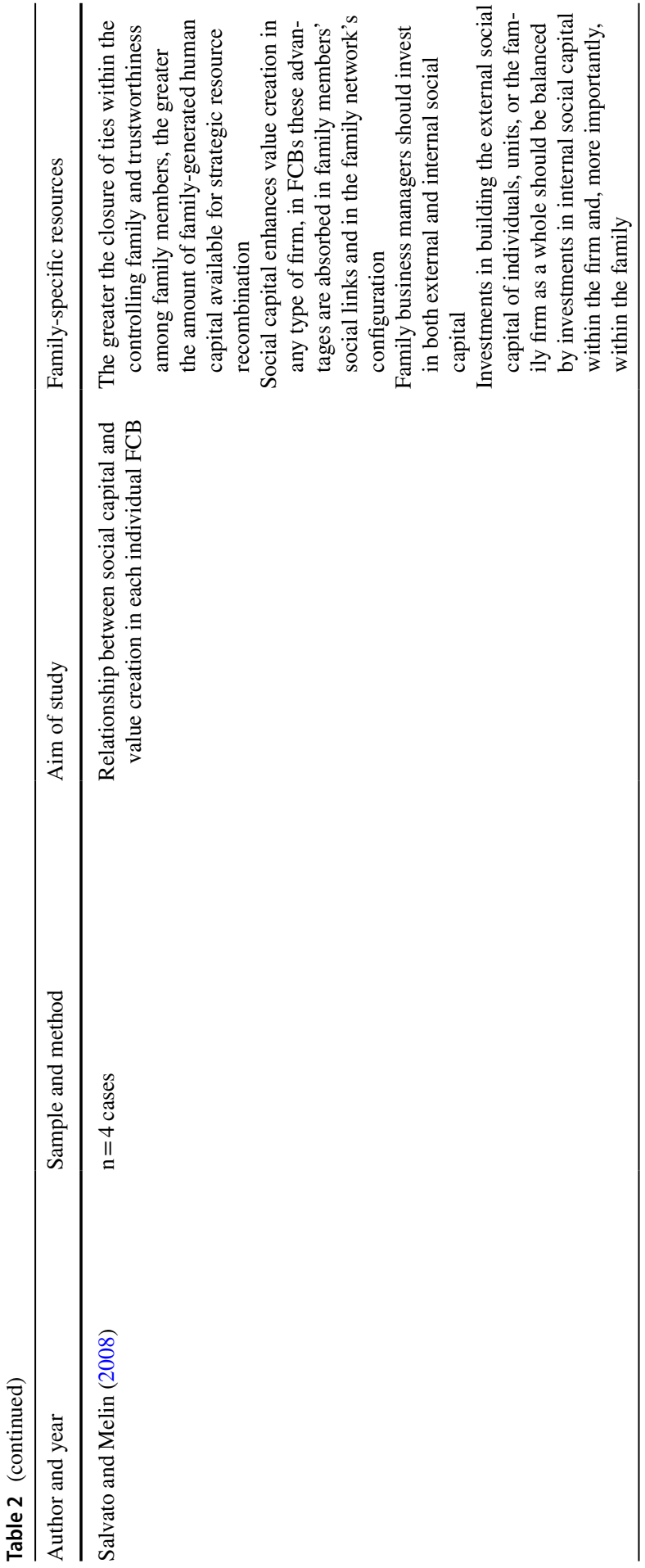




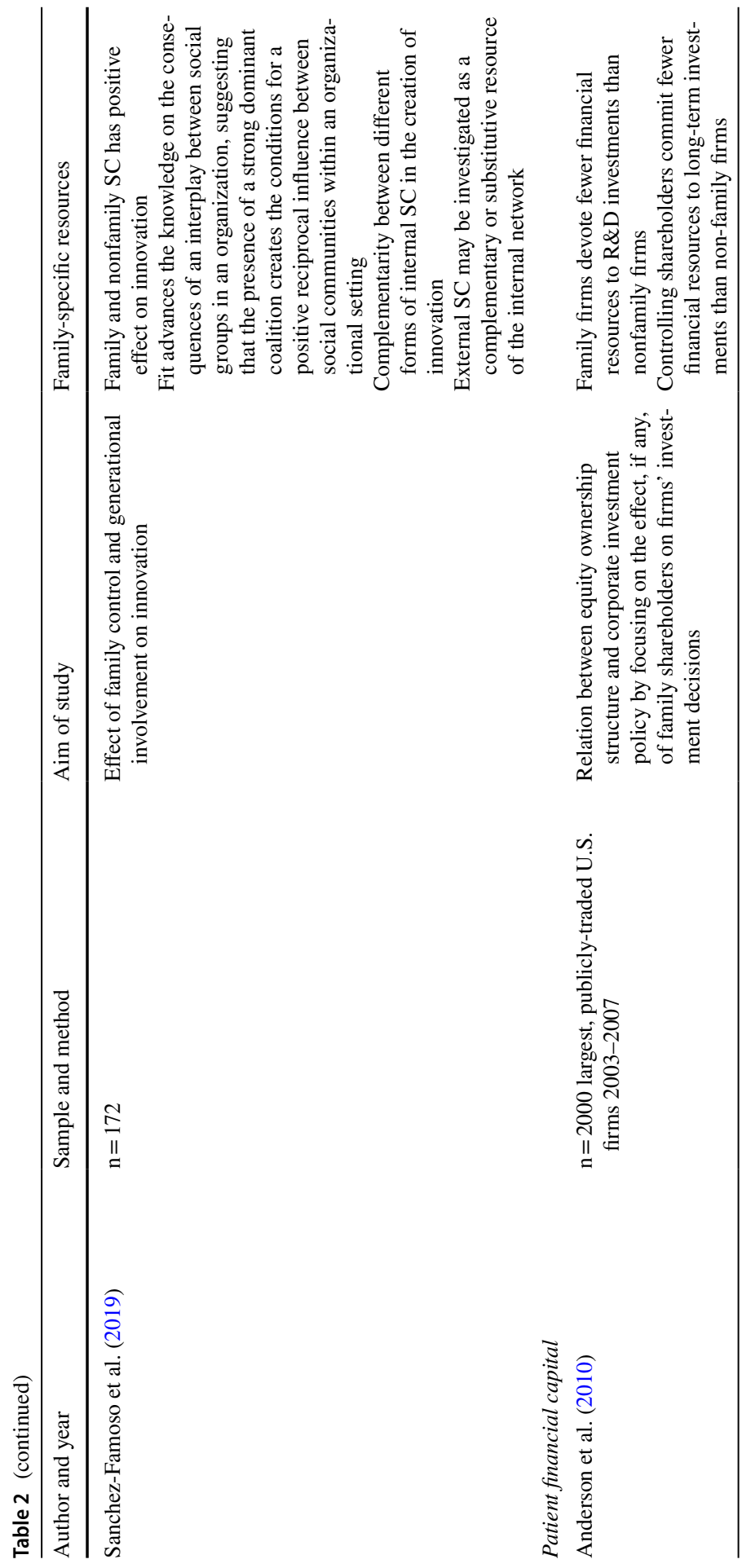




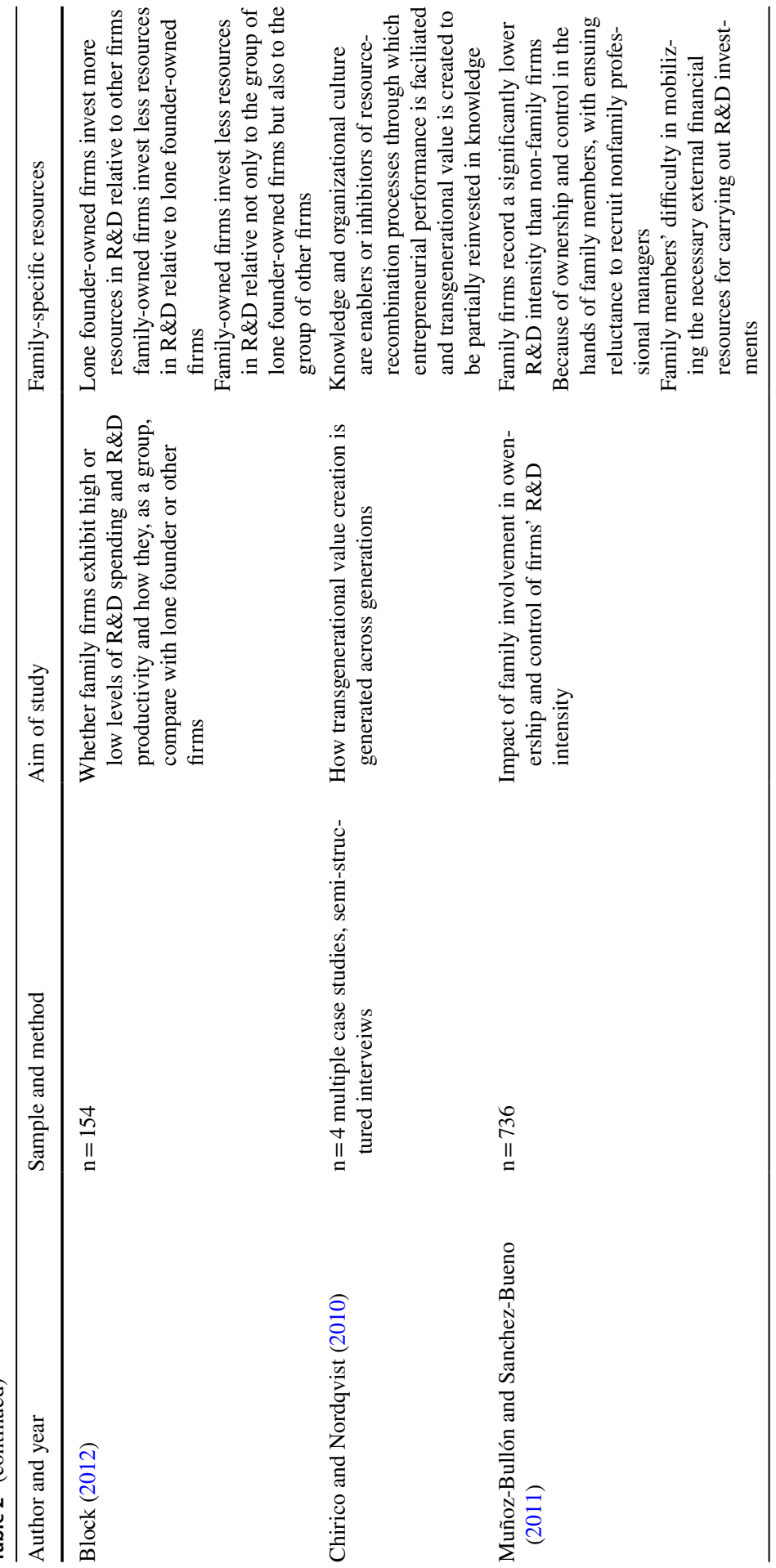




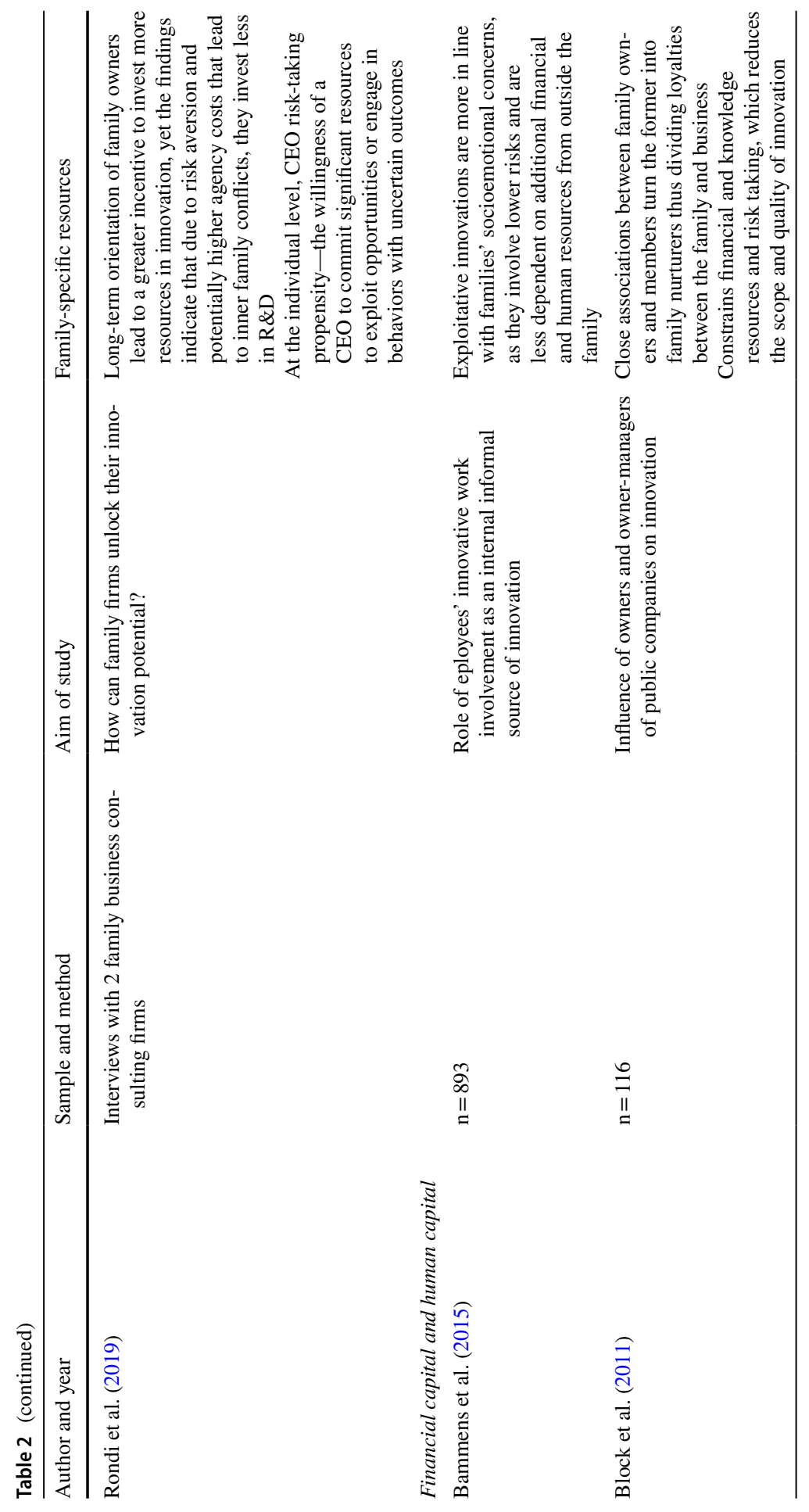




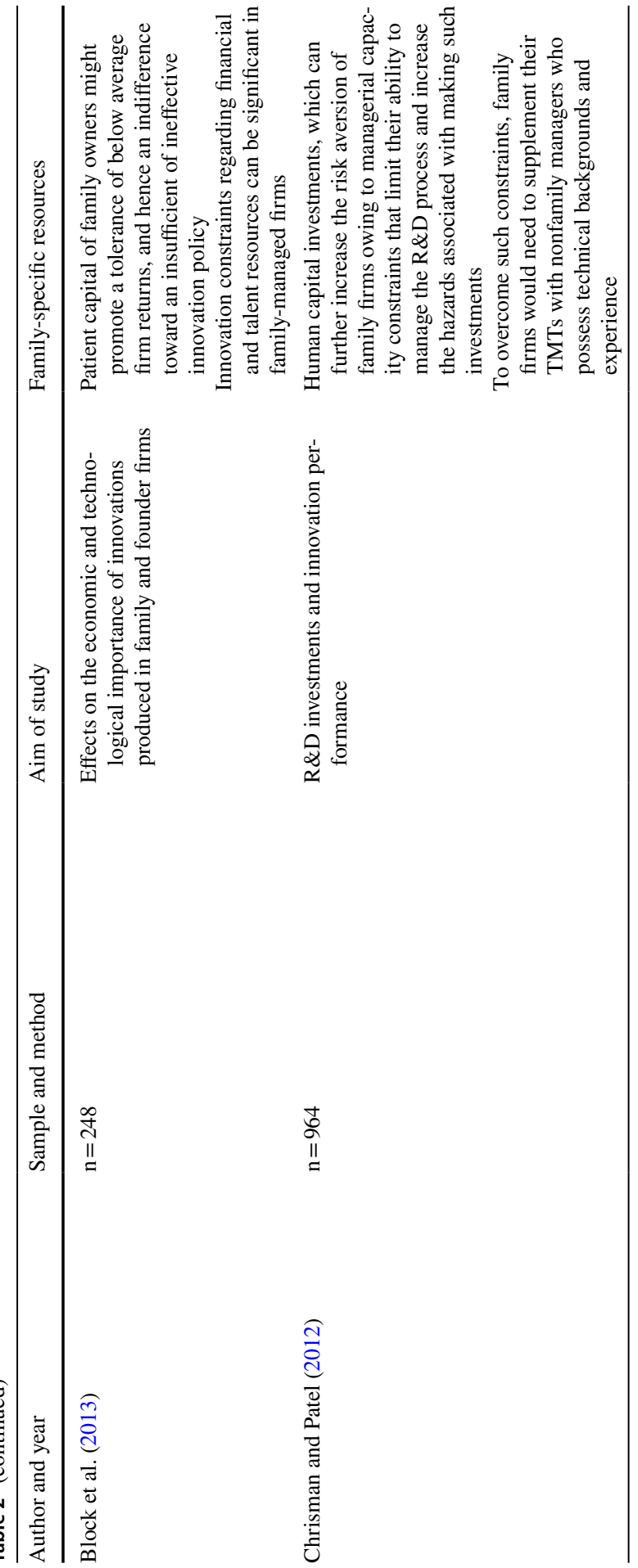




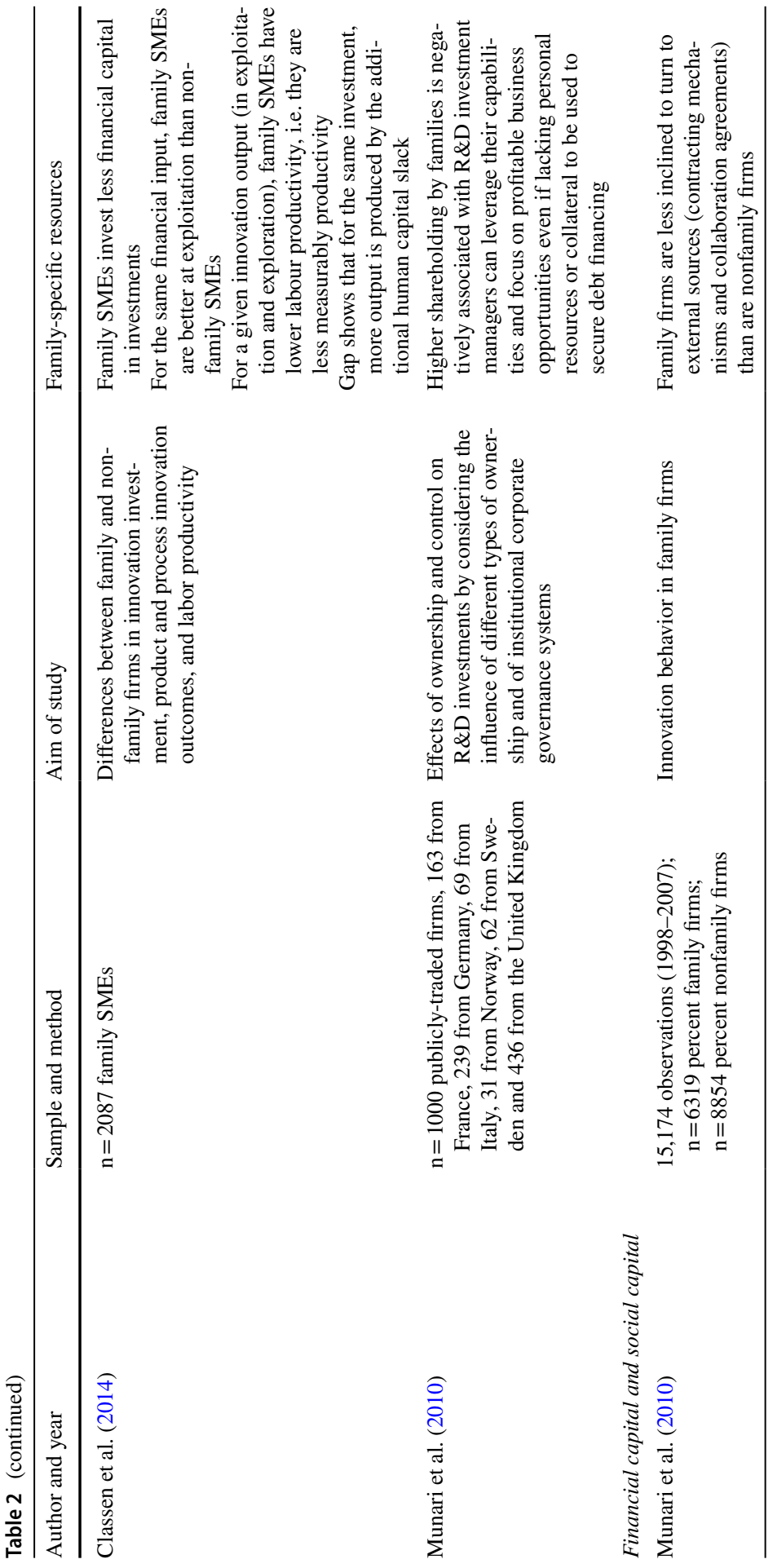


508

A. Heider et al.

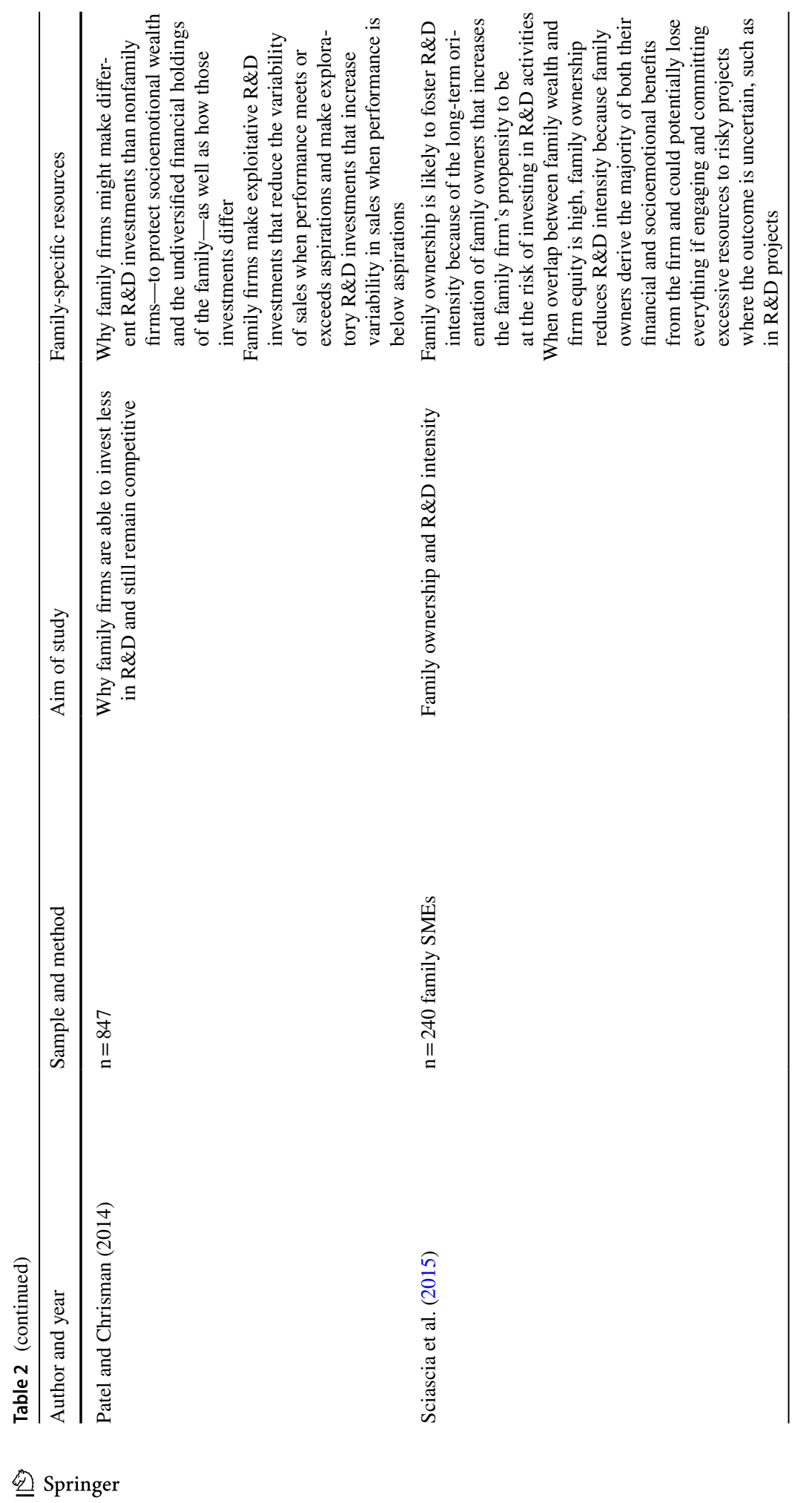




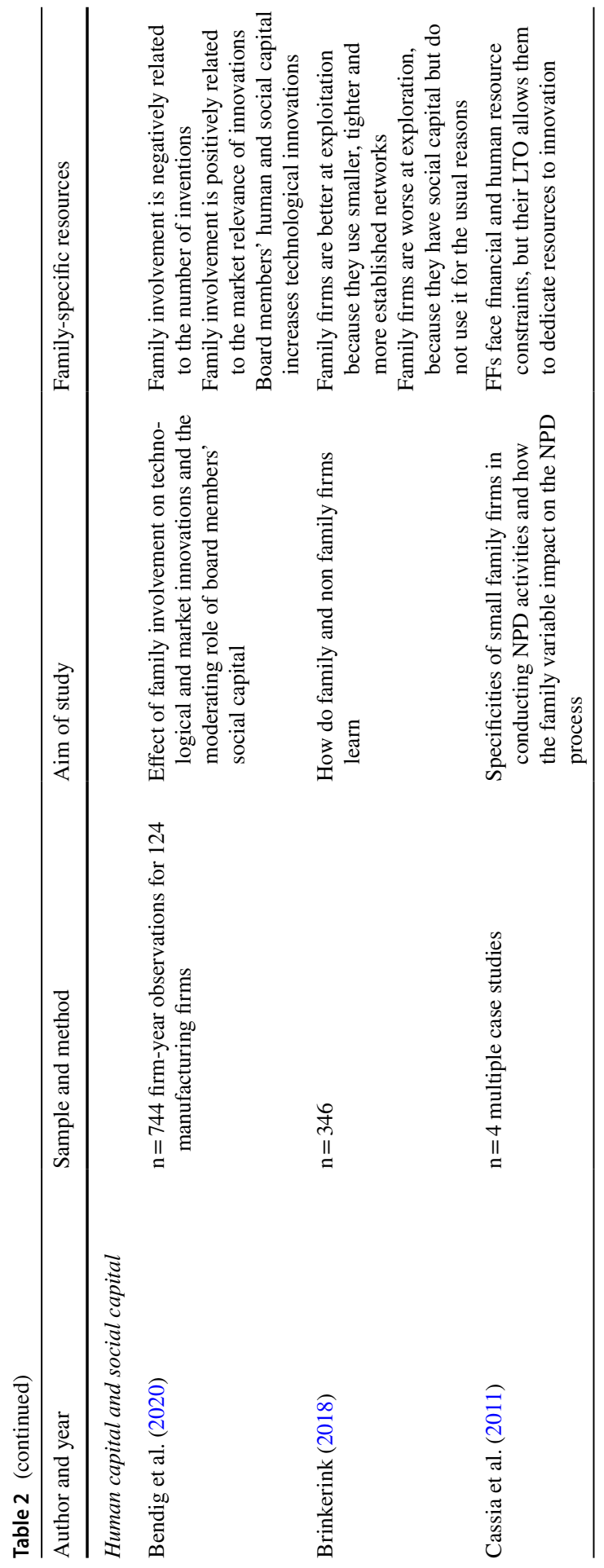




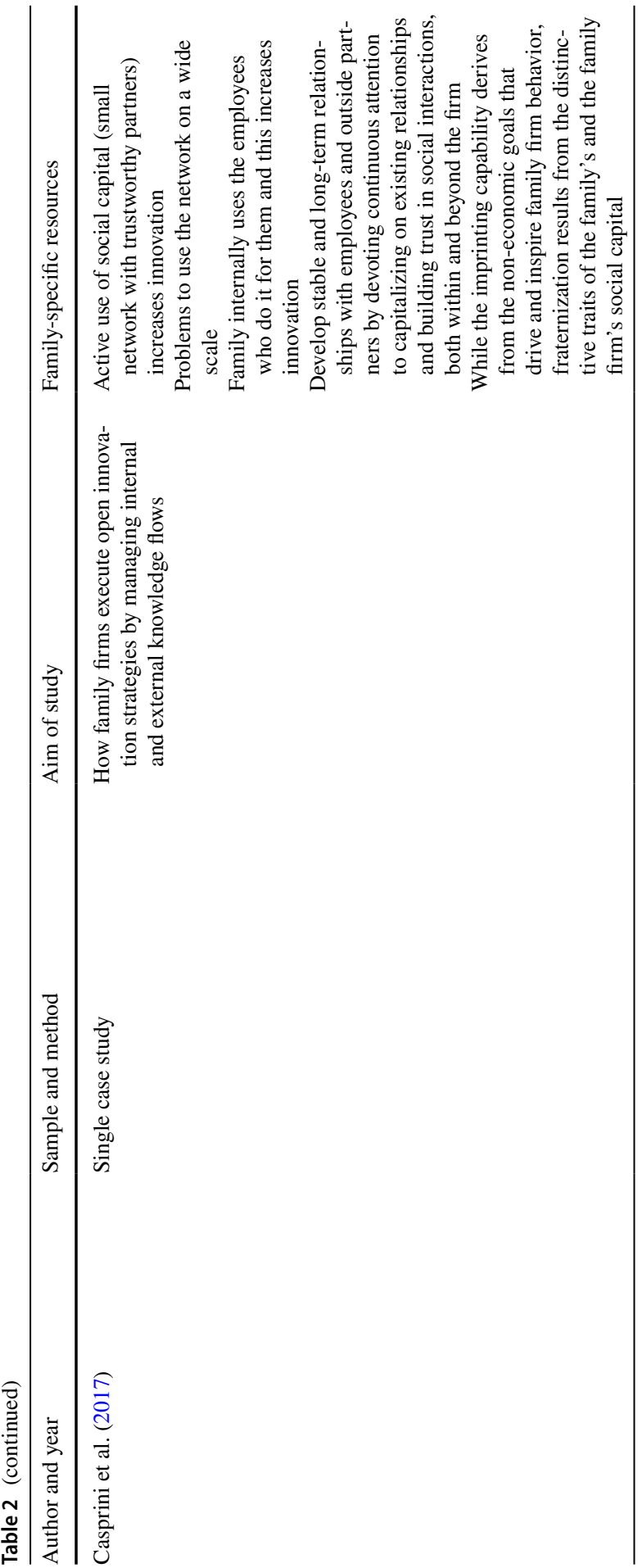




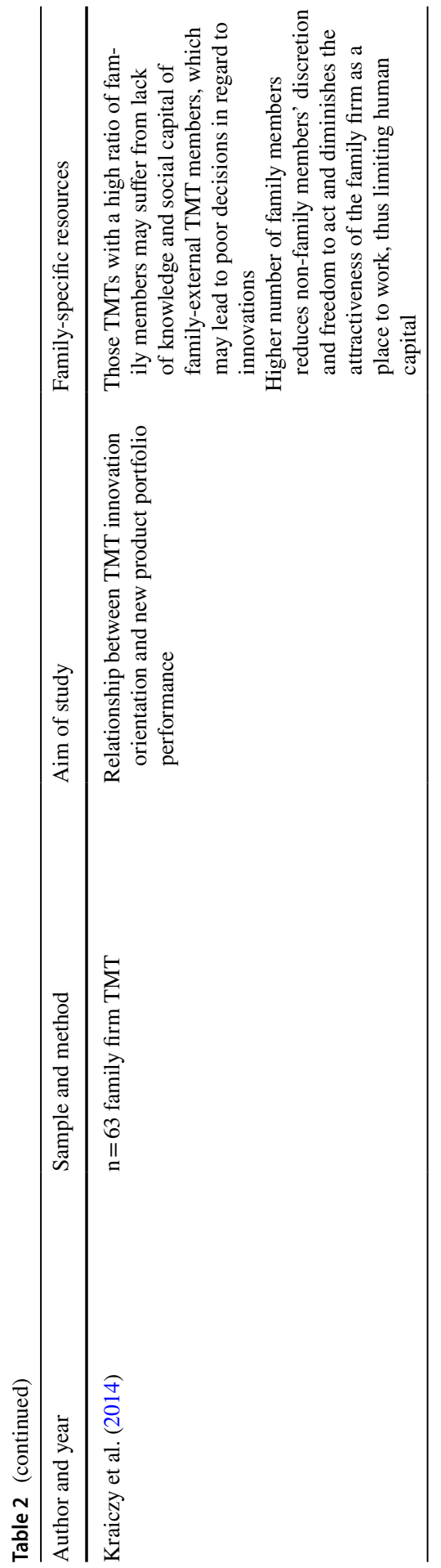




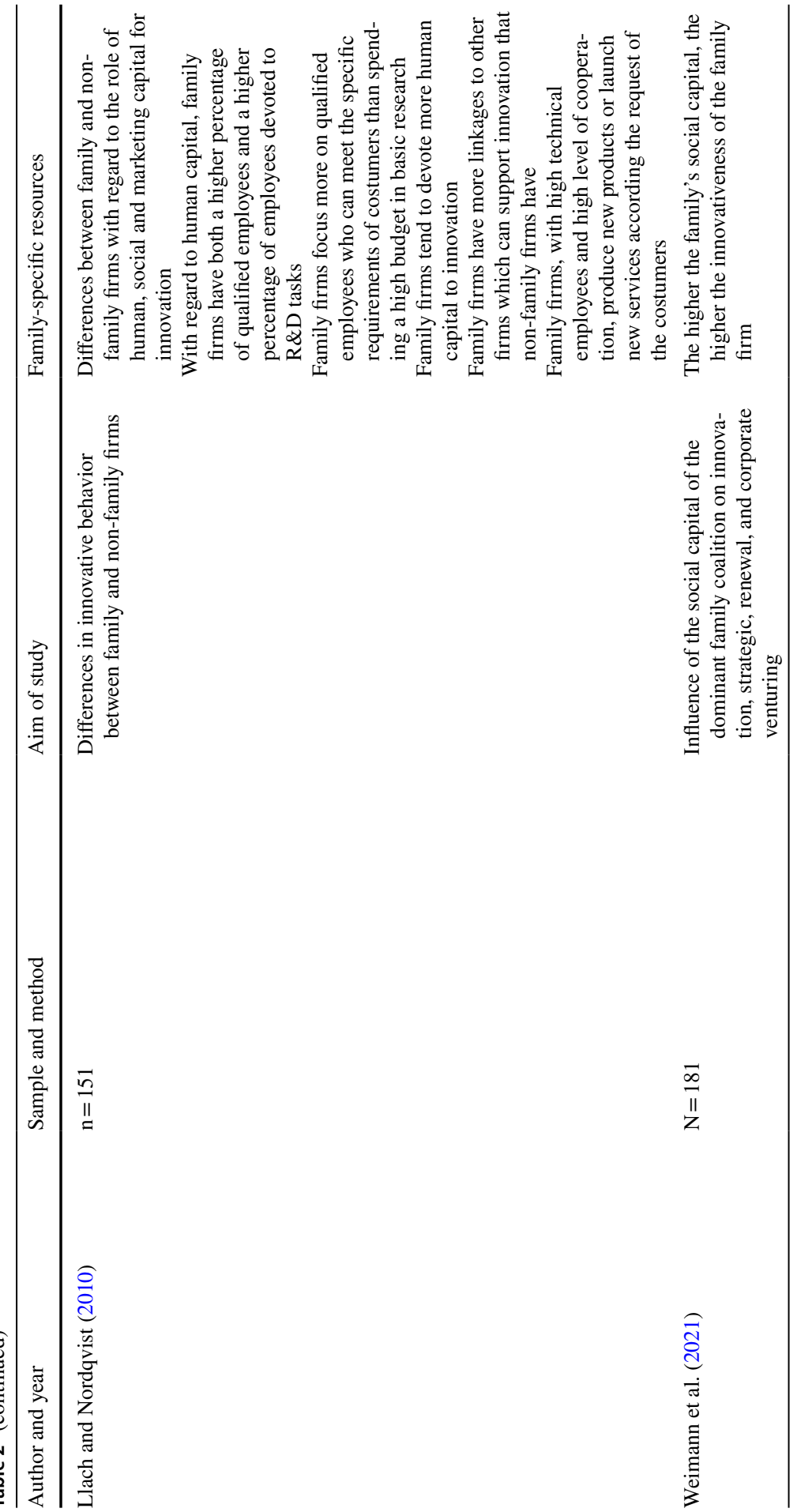




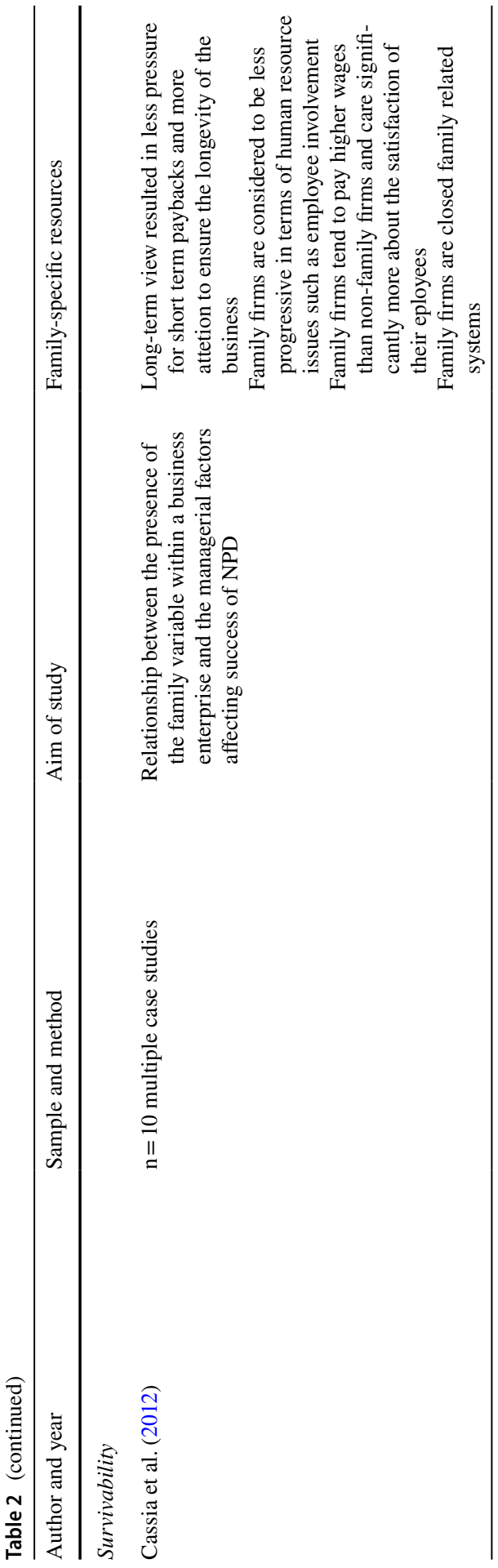




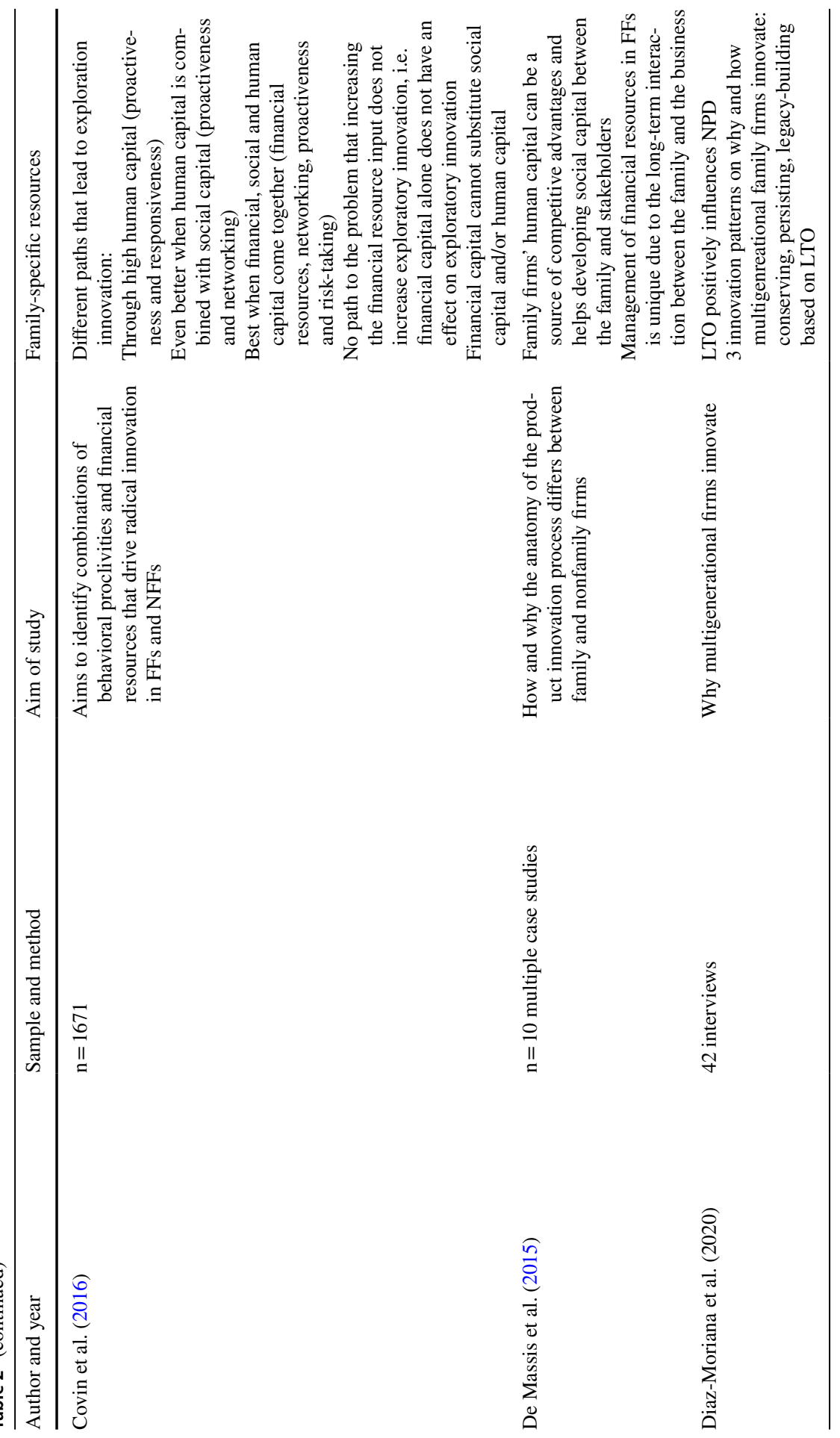




\section{Analysis}

The analysis of the 48 papers shows the influence of family firm specific resources on innovation. First, the influences of human capital, social capital and patient financial capital on innovation are analyzed. This is followed by an analysis of the interfaces of the individual family specific resources. The results of this analysis is conceptualized in our integrative model of how the interaction of family specific resources influences innovation.

\subsection{Influences of human capital on innovation}

Family businesses innovate differently because of their specific characteristics and the interpretation here is that family human capital should be considered as a central element in the innovation process in family firms. Chirico and Salvato (2016) describe the family social capital within the organization as special. According to this, family human capital manifests itself in proven cognitive schemata and interactions that result in their ability to implement implicit knowledge particularly well. Family members have the ability to transform knowledge, by combining existing with new knowledge, and to exploit gathered knowledge, by refining and extending existing competencies or creating new ones by using new and transformed knowledge. Family businesses that make use of their specialized human capital are better than those that do not (De Massis et al. 2016b), because those firms with conventional new product development designs are unable to muster adequate levels of human or financial resources and face conflicts between innovation activities and organizational routines.

Proposition 1a Innovation processes must be organized around family human capital.

Several studies show that professionalisation of innovation management through additional human capital leads to more innovation. In this context, Bergfeld and Weber (2011) argue that collaboration with managers and advisors that were not family members was dedicated to acquiring additional managerial and technological knowledge which helped the owning families to multiply the effect of their decisions and intentions within their firms and in intercompany collaborations. In consequence, family firms with less professional management remain disadvantaged when it comes to new product developmemt (Diéguez-Soto et al. 2016). A lack of TMT diversity is a sign of low human capital, which leads to a reduction of innovation (Serrano-Bedia et al. 2016). Informality and relationship orientation is a special form of human capital and it is sufficient if networking takes place between non-family members, the human capital of employees then substitutes the family. Diéguez-Soto et al. (2016) agree with findings with those of studies that state family TMTs restrain the positive relationship between R\&D investment and innovation performance as they are more efficient in exploiting given technological innovation outputs rather than increasing firm performance 
through exploration. The family firms' superior tacit knowledge is beneficial for harvesting advantageous human capital and allows leveraging unique resources more effectively. Family businesses involve more members due to their role width (overstaffing), thus achieving diversity and an adequate resource level. Conversion of technological innovation into performance is thus more efficient. Other studies show that more human capital in TMTs leads to higher exploratory innovation and a higher family influence has a negative impact on exploratory innovation (Arzubiaga et al. 2018). Family firms in third or later generations outperform first-generation ones and family firms with a mixed TMT (non-family members in the TMT) outperform purely family-managed family firms (Hillebrand et al. 2020). The results of this study show that TMT diversity increase R\&D inputs and exploration, not exploitation.

Proposition 1b Involvement of external managers in the TMT of family firms has a positive effect on exploratory innovation.

Matzler et al. (2015) show that only active involvement of the family creates an intersection between the firm and the family. Via these system interactions family-specific resource advantages come to light. Familial TMTs are therefore more efficient in exploiting their given $R \& D$ investments because they are more likely to engage in a process of social capital building. They suggest that family members are risk averse and reluctant to invest in innovation, but at the same time do so more efficiently. Because of risk aversion, they do less. This is because R\&D investments are always associated with uncertainty and family businesses tend to invest in security. Similar to the results of De Massis et al. (2016b), the literature here shows that family firms, due to their special characteristics such as forms of communication, quick decisions, and more efficient innovation management, leads to more exploitative innovation output. Calabrò et al. (2021) find not only a positive influence of human capital on family firm innovativeness, but are also able to show that family involvement in the board leverages this innovativeness.

Proposition 1c Family involvement in the TMT of the family firm leads to higher innovation efficiency.

Adaptability and family members' closeness to the firm are positively associated with perceiving the succession phase as an opportunity for innovation. Adaptability here is regarded as family-specific human capital. Successors are drivers of innovation and can act as a source of new information, knowledge and resources (Hauck and Prügl 2015). However, intergenerational authority and the history of family bonds are negatively related with the perception of the succession phase as suitable for innovation. The more adaptable the successors behave, the more likely the company is to exhibit higher innovation activity. If, on the other hand, there is a high path dependency, the firm is less innovative due to its rigidity. Here, a positive attitude towards the ability to deal with all successionrelated issues and conflicts is recommended. In this context, Kammerlander and 
Ganter (2015) find that CEO's noneconomic goals determine whether discontinous technologies are considered enough to react. Enduring ties, emotions and affect are a form of family-specific human capital, which leads to less innovation. In contrast, power, control, transgenerational value and family reputation lead to more innovation (Kammerlander and Ganter 2015).

Proposition 1d Higher family adaptability increases innovation output in family firms.

Proposition 1e Stronger family ties reduce innovation in family firms.

\subsection{Influences of social capital on innovation}

Because of the strong social capital resources family firms' innovation management is more flexible and less formalized than in non-family firms (De Massis et al. 2015). Long-term and close intra-family cooperation can lead to more in-depth discussion about the firm and the processes. As a result, knowledge can be shared and integrated in more efficiently between family members, increasing the family firms' ability to adapt its internal structures and external relations (Chirico and Salvato 2008). Therefore, family firms benefit from extensive and strong internal and external social capital resources. Although social capital enhances innovation in any type of the firm, these advantages are absorbed in family members' social links and in the family network's configuration. Investments in building the external social capital should be balanced by investment in internal social capital within the firm (Salvato and Melin 2008). While some studies find that family businesses use fewer cooperation partners than they could (Classen et al. 2012) other studies show the importance of family involvement to leverage firm relationships to innovation performance (Pucci et al. 2021). Family firms remain in small familiar networks due to their risk aversion, prefer long-term relationships, and invest in depth rather than breadth. Family firms have stronger networks than non-family firms, but they use them only selectively through partners who do not potentially harm them. While smaller firms suffer from limited resources, they benefit from more interaction and closer relationships between family members and employees, which can be translated in higher innovativeness. Hence, they use their social capital significantly more for exploitation, while at the same time doing less exploration (Pittino et al. 2013).

Proposition 2a Strong network embeddedness of family firms leads to exploitative innovation.

External social capital may be investigated as a complementary or substitute resource of the internal network (Sanchez-Famoso et al. 2019). Gómez-Mejía et al. (2014) find that successful R\&D investment can enhance the family owners' standing and reputation due to outperforming peers. Family owners will be prescient with regard to potential socioemotional gains, such as those deriving from economic success that may come from enhanced reputation or wider exposure of the family 
name. Because reputation is important to family firms, they invest more in R\&D. Long-term orientation of family owners would suggest they have a higher incentive to invest more resources in innovation, but Rondi et al. (2019) find that due to SEW loss aversion and potentially higher agency costs that lead to inner family conflicts, they invest less in R\&D. Moreover, compliance with institutional investors' wishes through greater R\&D spending enhances and protects SEW, because cooperation along these lines is likely to build social capital with institutions.

Proposition 2b Family firms invest in innovation to protect their SEW through social capital.

\subsection{Influences of patient financial capital on innovation}

Anderson et al. (2010) find that family firms invest less financial resources into R\&D than non-family firms because they try to keep resources together. Family firms record a significantly lower R\&D intensity than non-family firms (MuñozBullón and Sanchez-Bueno 2011). Ownership and control is in the hands of family members because they do not want to lose their control over the family firm. This makes it difficult for family owners to mobilize necessary external financial ressources for carrying out R\&D investments. Moreover, this need for control leads to a reluctance to recruit nonfamily professional managers, which prevents the influx of new human capital. On the other hand, the accumulation of specialized knowledge leads to a more efficient innovation management. As a result, they are often market leaders in niche markets, where they face less competition and less market uncertainties (Johann et al. 2021). This market position accommodates their risk aversion, but also limits their innovative capacity. Chirico and Nordqvist (2010) show that less risk averse family firms invest financially to compensate for their deficit in human capital. The higher the entrepreneurial orientation is, the more they use financial resources to compensate for the deficit in human capital. They use financial resources to acquire new knowledge or implement existing ones through training, executive courses, employing external non-family members. There is a trade-off between human and financial capital when it comes to innovation in family firms: both forms of capital can act as a substitute for the other form of capital. Family firms with high lock-ins into specialized family human capital can use financial capital to become more innovative while risk averse and resource constrained family firms can mobilize their human capital towards the same end.

Proposition 3 Family firms can compensate a lack of financial capital by investing into human capital to increase innovation and vice versa. 


\subsection{Influences of financial capital and human capital on innovation}

By pursuing socio-emotional factors, family firms tend to make exploitative innovations. Bammens et al. (2015) assume that exploitative innovations involve lower risks and are less dependent on additional financial and human resources from outside the family. This effect is reinforced by the fact that no human capital is built up. The adoption of caring, relational approaches to solicit innovative ideas and suggestions from employees may increase exploitative innovation outputs. Block et al. (2011) argue in a similar way; they find that the focus on family preservation changes the preference of the family owner and prevents financial investments. Family owners and managers spend less on innovation input and also obtain less output and quality. The reason is that close associations between family owners and members turn the former into family nurturers thus dividing loyalties between the family and business. This constrains financial and knowledge resources and risk taking, which reduces the scope and quality of innovation. Block et al. (2013) argue that human capital leads to more exploitative innovation. Family-managed firms receive fewer patent citations in comparison with other firms. This result can be explained by the lower returns on innovation of a family business. As they have capital tied up in the long-term (patient capital), they do not feel the pressure to innovate. Chrisman and Patel (2012) show that human capital investments, which can further increase the risk aversion of family firms owning to managerial capacity constraints that limit their ability to manage the $R \& D$ process and increase the hazards associated with making such investments. To overcome such constraints, family firms would need to supplement their TMTs with non-family managers who possess technical knowledge. Managers can leverage their capabilities and focus on profitable business opportunities even if lacking personal resources or collateral to be used to secure debt financing. Given the same financial input, family firms are better at exploitation than non-family firms. For a given innovation output (exploitation and exploration), Classen et al. (2014) show that family firms have lower labour productivity, i. e. they are less productive. For the same investment, more innovation output is produced by the additional human capital.

Proposition 4 Given the same financial investment into innovation, family firms benefit more by additional investments into human capital than non-family firms.

\subsection{Influences of financial capital and social capital on innovation}

Innovation activities are costly and risky and therefore an unattractive option for conservative family firms, which have limited financial resources. While family firms are limited in financial resources and opportunities to finance innovation activities, they can create social capital easily (Nieto et al. 2015). Pucci et al. (2020) show that family firms are especially more able to utilize their social capital to amplify their innovation outcomes. Although, they can easily generate social capital, they often do not use it, because they fear losing control and are 
anxious to protect their specific knowledge. Risk aversion and loss of control therefore lead to underinvestment into innovation. Bendig et al. (2020) investigate the role of family involvement in boards of directors for technological and market innovation. They show that the negative effect of family involvement on innovation can be alleviated by the board's social capital.

Proposition 5 Family firms that actively use their social capital to mitigate limited financial resources have higher innovation outcomes.

\subsection{Influences of human capital and social capital on innovation}

Family firms face financial and human resource constraints, but their long-term orientation allows them to dedicate resources to innovation (Cassia et al. 2011). The analysis of this interface again confirms the argument that family firms are better at exploitation because they use smaller, tighter and more established networks, whereas family firms are worse at exploration, because they have social capital but do not use it as we have seen before (Brinkerink 2018). With regard to human capital, Llach and Nordqvist (2010) show that family firms have a higher percentage of qualified employees devoted to R\&D tasks. These results suggest that family firms focus more on qualified employees who can meet the specific requirements of customers than spending a high budget in basic research. Therefore, family firms tend to devote more human capital to innovation and those with a high number of technical employees have more linkages to other firms and a higher level of cooperation. While Bendig et al. (2020) show that family firms produce less technological innovations with more market relevance, they also find a positive moderating effect of the human and social capital of board members on technological innovation. This high social capital enables board members to acquire new external knowledge and their human capital legitimizes the appropiation within the firm. Similar positive effects can be found when considering the family owners internal human and external social capital (Weimann et al. 2021).

In summary, the analysis shows that the active use of employee social capital increases innovation. Casprini et al. (2017) show that family firms have problems to scale up their network beyond a few trusted partners. As family firms develop stable and long-term relationships with employees and outside partners by devoting continous attention to capitalizing on existing relationships and building trust in social interactions, they are able to use employees social capital to bridge the void between themselves and a wider network.

Proposition 6 Family firms that capitalize on their employees' social capital have higher innovation outcomes. 


\subsection{The role of family firm specific resources in innovation}

Family firms' human capital can be a source of competitive advantages and helps developing social capital between the family and stakeholders. The management of financial resources in family firms' is unique due to the long-term interaction between the family and the business (De Massis et al. 2015). The long-term view results in less pressure for short-term paybacks and more attention to ensure the longevity of the business. Family firms are considered to be less progressive in terms of human resources issues such as employee involvement. Cassia et al. (2012) argue that family firms face financial and human resource constraints, but their long-term orientation allows them to dedicate resources to innovation. Covin et al. (2016) show different paths that lead to explorative innovation. The easiest path to achieve explorative innovation is through human capital (proactiveness and responsiveness). Therefore, this is also the starting point of our conceptual model. When human capital is combined with social capital (proactiveness and networking) it is even better. The best path is when financial capital, social capital and human capital come together (financial resources, networking, proactiveness and risk-taking). We understand this path as resource bundling. Overall it can be observed that there is no path over the problem that increasing the financial resource does not increase exploratory innovation, which means that financial capital alone does not have an effect on exploratory innovation. From this result we can conclude that financial capital cannot substitute the social capital and the human capital (Fig. 2).

Moreover, the analysis of family-specific resources provides results and approaches to solve the explain the heterogeneity in family firms. We can identify a virtuos circle which leads to rotative overinvestment into exploitative innovations. On the one side restricted human capital leads to underinvestment of financial capital in exploratory or radical innovation. On the other side the patient financial capital lowers the pressure on human capital investments into exploratory innovations.

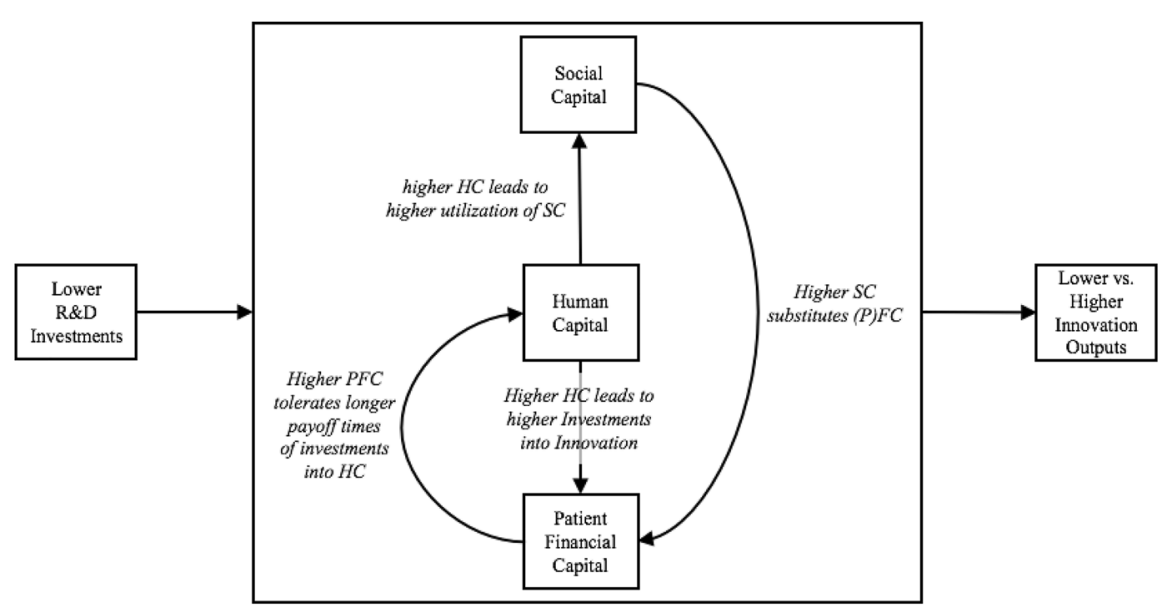

Fig. 2 The interplay of family firm specific resources 
Therefore, a key finding is that investment in human capital can help to explain the heterogeneity because human capital activates social capital and substitutes the deficits in financial capital. Higher human capital enhances social capital utilization and social capital integrates financal capital restrictions. The major challenge is to increase growth, profit and sustainability by achieving the proper balance between the familiy firms' resources and its innovation capacity. Moreover, family firms consider innovation and creativity as less important and are less oriented toward innovation and growth and more resistant to change than non-family firms. The conflicting relationship between family firms and innovation arises from the interplay of their long-term orientation and conservatism (i.e. tradition, avoidance of risk to destroy family wealth).

\section{Avenues for future research}

Making theoretical contributions with review articles requires combining integrative and generative approaches, which can move a review's contribution beyond a summary of prior research directions towards a fundamental theoretical contribution (Post et al. 2020). Accordingly, the integrative aspect involves the analysis and synthesis of existing research on innovation in family businesses. The generative aspect refers to the development of new ideas and theories based on the analysis of previous studies (Torraco 2016; Gatrell and Breslin 2017).

On the basis of our integrative literature review and the detailed analysis of relevant studies on family firm innovation, we conclude that-despite the huge interest in the field-the relationship between family firms and innovation remains poorly understood (De Massis et al. 2013; Duran et al. 2016; Calabrò et al. 2019). With respect to the former, that is the impact of family involvement on innovation inputs, we find that the existing research merely examines whether or not family firms are more or less innovative than their non-family counterparts. However, the findings from these studies produce mixed results without explaining the family firm innovation heterogeneity. With respect to the latter, that is the impact of family involvement on innovation outputs, we find that most of the studies apply a rather simplified partial view of innovation only on single types of innovation: e.g. technological product and/or process innovation (Classen et al. 2012; De Massis et al. 2013).

The analyzed studies emphasized the relationship between the family firm specific resources and innovation but overlooked the heterogeneity of family firms. In the previous research are already some literature reviews and one meta-analysis about innovation in family firms (Calabrò et al. 2019, Filser et al. 2016; PadillaMeléndez 2015; De Massis et al. 2013; Duran et al. 2016). All of them follow the narrative that family firms seem to be able to yield higher innovation outputs from lesser innovation inputs under resource constraints. None of the recent studies state how family firms are able to generate higher outputs with fewer resources. Therefore, the aim of this paper was to look at the so called black box to examine how family firms achieve this what kind of innovation performance. So far, it is known that family businesses have specific resources, but not in what way these resources are bundled and have an impact on innovation. That is, family firms appear to rely 
on unique resources bundles as the underlying condition for innovation, but the composition and confirmation of the bundles remain unknown. In this context, we show that the configuration and bundling of family firm specific resources is the missing link in explaining this gap. By developing our model we are able to explain how the interplay of family firm specific resources can leverage innovation processes. An unresolved problem, however, is about what resource stocks and bundles should consist of and whether specific resource histories and trajectories create lock-ins that further hinder family firm innovation. This requires a shift in theoretical assumptions set around the ownership of resources and towards the composition of the resources held or accessible by the family firm.

In order to address these very important research gaps and opportunities, future research should increasingly take into account the heterogeneity of family firms so as to create a better understanding of their idiosyncratic resources and how they influence innovation. The great variability among family firms, for example, in terms of size, generation or degree of family involvement in ownership, management and/or governance largely affect their propensity toward innovation. Innovation outputs, whether these are new products, services or business models, are very likely to differ on the basis of firm size.

Our analysis has shown that higher human capital leads to higher innovation in family firms. We find that there is already a great deal of research on governance to increase human capital. However, there is little research on how to increase human capital. From TMT board research we know that diversity in family firms leads to higher innovation, for example through female managers, successors or external TMT members. A possible approach for future research is the paper by Arzubiaga et al. (2018), which deals with skills and roles. Further starting points for a future research agenda can be found in the area of HR practices in family firms. Rondi et al. (2021) examine how long-term orientated family firms' can simultaneously innovate and manage its human resources, ensuring mutual gains for the firm and its employees. Future research could explore the role that different groups and individuals, either family or non-family members, play in shaping mutual gains. We acknowledge that the family firm literature has dedicated much attention to examining the different treatments that owning-families adopt toward family and non-family employees, leading to phenomena such as nepotism, bifurcation bias (Rondi et al. 2021).

Overall, research on social capital in family firms shows that family businesses have smaller, closer networks based on trusting relationships. Many studies show that family businesses have social capital, but do not use it widely because they are afraid of losing control. A future research question here could be how family businesses manage to overcome this and how they seek the breadth rather than the depth of the network. This is followed by the question of how family businesses can pursue open innovation approaches. Heider et al. (2021) point out that dynamic capabilities as an approach lead to a search to the outside (sensing). There are indications from Dynamic Capabilities Research that an external search can help. One question here could be how networks can be activated in the future. For example, network analyses could be conducted to see how the underlying network is structured. There 
is already research about the role of family members in entrepreneurial networks (Anderson et al. 2005).

In the area of financial capital, the results are well researched (e.g. on R\&D investments) and the findings are relatively clear. Overall, family firms invest less for the reasons already known. On the one hand we find a negative effect in patient financial capital, due to family investors' acceptance of below market returns on their investments. This lowers the innovative pressure within the company. On the other hand, a positive effect of patient financial capital is a higher tolerance of longterm payoff periods leading to a long-term investment strategy. The actual positive or negative effect of patient financial capital is possibly moderated by the invstors' attitude toward the firm. For example a tight-knit, highly identified, and small family group might tolerate lower returns than a larger and more diverse owner-groups expecting higher returns. Future research could investigate how family structure and attitude influences the effect of patient financial capital on innovation. How does social proximity or distance affect the capital market orientation and hence the innovation output of a family firm?

Considering the interplay of human and social capital questions arise how family businesses acquire the relevant human capital to leverage social network resources. One question could be in how far a successor can renew and establish new social networks beyond the exisiting ones in a company through his or her education and job experience (e.g. experiences within the Start-up eco-system). At the same time, research on top management teams and boards of directors has shown the beneficial effects of using their networks strategically. The question if and how family firms can utilize board networks to leverage social capital for innovation has not been answererd yet.

As we have argued higher human capital leads to higher financial capital investments into innovation. The question remains, whether this increase of human capital only changes the quantity of financial capital investments or whether it changes the quality of investments at the same time. It is possible that a higher absorptive capacity and/or reduced risk aversion will change the portfolio of innovation investments at the same time. Future research could start with the question whether a change in the level of investment also changes the type of innovation projects. Moreover, the studies show that higher social capital can substitute for patient financial capital. Substitution works through spillovers, accessing resources and knowledge from outside without paying the full price. However, spillovers only work under certain conditions, through social, technological, and/or regional aglomeration effect, such as dense urban areas. Future research could look at the conditions under which social capital generates spillovers. Here, research on regional economics provides some indications of how spillovers work and under what conditions family firms can reap their benefits (e.g. regional clusters).

Concerning practical implications the level and importance of human capital is the primary driver of exploratory innovation. In this framework, the question arises of how to achieve higher human capital. This can be achieved, for example, through structured talent management, the recruitment of appropriate employees and early succession planning. Furthermore, human resource development should pursue the general goal of increasing the diversity and quality of human capital. The investment 
in human capital activates social capital. The higher and diverse human capital leads on the one hand to broader networks with more stakeholders through personal contacts, which in turn leads to a higher knowledge flow and at the same time increases the absorptive capacity because the existing stakeholders increase responsiveness and sensitivity. This can be achieved by participating in activities outside the firm, such as university collaborations, in order to build and use the relevant networks. Higher existing human capital and higher activation from the environment of the firm enables better investment decisions to be made. Those who would invest more financial capital but are unable to do so due to resource constraints can compensate for their financial resource scarcity by engaging more in social networks.

Given that family firms represent the predominant type of organization worldwide, the research on family firms is still relatively young, but their importance across most economies has already been acknowledged. Scholars have also shown that innovation consitutes a major determinant for their long-term success over generations, but technological innovation alone will no longer be sufficient to remain competitive. This is why we observe a huge interest in innovation from scholars and practicioners. As we have shown, there are strong theoretical reasons to believe that innovation in family firms differs from that found in non-family firms and even between family firms due to their heterogeneity.

Funding Open Access funding enabled and organized by Projekt DEAL.

\section{Declarations}

Conflict of interest We have no conflicts of interest or additional sources of funding to disclose.

Open Access This article is licensed under a Creative Commons Attribution 4.0 International License, which permits use, sharing, adaptation, distribution and reproduction in any medium or format, as long as you give appropriate credit to the original author(s) and the source, provide a link to the Creative Commons licence, and indicate if changes were made. The images or other third party material in this article are included in the article's Creative Commons licence, unless indicated otherwise in a credit line to the material. If material is not included in the article's Creative Commons licence and your intended use is not permitted by statutory regulation or exceeds the permitted use, you will need to obtain permission directly from the copyright holder. To view a copy of this licence, visit http://creativecommons.org/licen ses/by/4.0/.

\section{References}

Adler P, Kwon S (2002) Social capital: prospects for a new concept. Acad Manag Rev 27(1):17-40

Anderson AR, Jack SL, Dodd SD (2005) The role of family members in entrepreneurial networks: beyond the boundaries of the family firm. Fam Bus Rev 18(2):135-154

Anderson R, Duru A, Reeb D (2010) Family preferences and investment policy: evidence from R\&D spending and capital expenditures. American University and Temple University Working Paper

Arzubiaga U, Kotlar J, De Massis A, Maseda A, Iturralde T (2018) Entrepreneurial orientation and innovation in family SMEs: unveiling the (actual) impact of the Board of Directors. J Bus Ventur 33:455-469 
Bakker RM (2010) Taking stock of temporary organizational forms: a systematic review and research agenda. Int J Manag Rev 12(4):466-486

Bammens Y, Notelaers G, Van Gils A (2015) Implications of family business employment for employees' innovative work involvement. Fam Bus Rev 28(2):123-144

Barney J (1991) Firm resources and sustained competitive advantage. J Manag 17(1):99-120

Bendig D, Foege JN, Endriß S, Brettel M (2020) The effect of family involvement on innovation outcomes: the moderating role of board social capital. J Prod Innov Manag 37(3):249-272

Bennedsen M, Foss N (2015) Family assets and liabilities in the innovation process. Calif Manag Rev 58(1):65-81

Bergfeld M-M, Weber F (2011) Dynasties of innovation: highly performing German family firms and the owners' role for innovation. Int J Entrep Innov Manag 13(1):80-94

Block J (2012) R\&D investments in family and founder firms: an agency perspective. J Bus Ventur 27(2):248-265

Block J, Miller D, Jaskiewicz P, Spiegel F (2011) Innovation in founder and firms: entrepreneurial versus nurturer identities of owners. Front Entrep Res 31(13):1-15

Block J, Miller D, Jaskiewicz P, Spiegel F (2013) Economic and technological importance of innovations in large family and founder firms: an analysis of patent data. Fam Bus Rev 26(2):180-199

Booth A, Papaioannou D, Sutton A (2012) Systematic approaches to a successful literature review. Sage Publications, London

Brinkerink J (2018) Broad search, deep search, and the absorptive capacity performance of family and nonfamily firm R\&D. Fam Bus Rev 31(3):295-317

Broekaert W, Andries P, Debackere K (2016) Innovation processes in family firms: the relevance of organizational flexibility. Small Bus Econ 47(3):771-785

Bucherer E, Eisert U, Gassmann O (2012) Towards systematic business model innovation: lessons from product innovation management. Creat Innov Manag 21(2):183-198

Cabrera-Suárez K, Saá-Pérez P, García-Almeida D (2001) The succession process from a resource-and knowledge-based view of the family firm. Fam Bus Rev 14(1):37-46

Calabrò A, Vecchiarini M, Gast J, Campopiano G, Massis De, Kraus S (2019) Innovation in family firms: a systematic literature review and guidance for future research. Int J Manag Rev 21(3):317-355

Calabrò A, Torchia M, Jimenez DG, Kraus S (2021) The role of human capital on family firm innovativeness: the strategic leadership role of family board members. Int Entrep Manag J 17(1):261-287

Carnes CM, Ireland D (2013) Familiness and innovation: resource bundling as the missing link. Entrep Theory Pract 37(6):1399-1419

Carney M (2005) Corporate governance and competitive advantage in family-controlled firms. Entrepreneurship Theory and Practice 29(3):249-265

Casprini E, De Massis A, Di Minin A, Frattini F, Piccaluga A (2017) How family firms execute open innovation strategies: the Loccioni case. J Knowl Manag 21(6):1459-1485

Cassia L, De Massis A, Pizzurno E (2011) An exploratory investigation on NPD in small family businesses from Northern Italy. Int J Bus Manag Soc Sci 2(2):1-14

Cassia L, De Massis A, Pizzurno E (2012) Strategic innovation and new product development in family firms: an empirically grounded theoretical framework. Int J Entrep Behav Res 18(2):198-232

Chen H-L, Hsu W-T (2009) Family ownership, board independence, and R\&D investment. Fam Bus Rev 22(4):347-362

Chesbrough H (2007) Business model innovation: it's not just about technology anymore. Strateg Leadersh 35(6):12-17

Chesbrough H (2010) Business model innovation: opportunities and barriers. Long Range Plan 43(2):354-363

Chirico F, Nordqvist M (2010) Dynamic capabilities and trans-generational value creation in family firms: the role of organizational culture. Int Small Bus J 28(5):487-504

Chirico F, Salvato C (2008) Knowledge integration and dynamic organizational adaption in family firms. Fam Bus Rev 21(2):169-181

Chirico F, Salvato C (2016) Knowledge internalization and product development in family firms: when relational and affective factors matter. Entrep Theory Pract 40(1):201-229

Chrisman J, Patel P (2012) Variations in R\&D investments of family and nonfamily firms: behavioral agency and myopic loss aversion perspectives. Acad Manag J 55(4):976-997

Chrisman J, Sharma P, Steier L, Chua J (2013) The influence of family goals, governance, and resources on firm outcomes. Entrep Theory Pract 37(6):1249-1261 
Chrisman J, Chua J, De Massis A, Frattini F, Wright M (2015a) The ability and willingness paradox in family firm innovation. J Prod Innov Manag 32(3):310-318

Chrisman J, Fang H, Kotlar J, De Massis A (2015b) A note on family influence and the adoption of discontinuous technologies in family firms. J Prod Innov Manag 32(3):384-388

Christensen C (2013) The innovator's dilemma: when new technologies cause great firms to fail. Harvard Business Review Press, Harvard

Chua J, Chrisman J, Steier L, Rau S (2012) Sources of heterogeneity in family firms: an introduction. Entrep Theory Pract 36:1103-1113

Classen N, Van Gils A, Bammens Y, Carree M (2012) Accessing resources from innovation partners: the search breadth of family SMEs. J Small Bus Manag 50(2):191-215

Classen N, Carree M, Van Gils A, Peters B (2014) Innovation in family and non-family SMEs: an exploratory analysis. Small Bus Econ 42(3):595-609

Covin JG, Eggers F, Kraus S, Cheng C-F, Chang M-L (2016) Marketing-related resources and radical innovativeness in family and non-family firms: a configurational approach. $\mathrm{J}$ Bus Res 69:5620-5627

Craig J, Dibrell C (2006) The natural environment, innovation, and firm performance: a comparative study. Family Business Rev 19(4):275-288

Cucculelli M, Bettinelli C (2015) Business models, intangibles and firm performance: evidence on corporate entrepreneurship from Italian manufacturing SMEs. Small Bus Econ 45(2):329-350

David RJ, Han SK (2004) A systematic assessment of the empirical support for transaction cost economics. Strateg Manag J 25:39-58

Danes SM, Lee J, Stafford K, Heck RKZ (2008) The effects of ethnicity, families and culture on entrepreneurial experience: an extension of sustainable family business theory. J Dev Entrep 13:2229-2268

Danes SM, Stafford K, Haynes G, Amarapurkar SS (2009) Family capital of family firms. Bridging human, social and financial capital. Fam Bus Rev 22(3):199-215

Dawson A (2012) Human capital in family businesses: focusing on the individual level. J Fam Bus Strateg 3(1):3-11

De Massis A, Frattini F, Lichtenthaler U (2013) Research on technological innovation in family firms: present debates and future directions. Fam Bus Rev 26(1):10-31

De Massis A, Frattini F, Pizzurno E, Cassia L (2015) Product innovation in family versus nonfamily firms: an exploratory analysis. J Small Bus Manag 53(1):1-36

De Massis A, Frattini F, Kotlar J, Petruzzelli A, Wright M (2016a) Innovation through tradition: lessons from innovative family businesses and directions for future research. Acad Manag Perspect 30(1):93-116

De Massis A, Kotlar J, Frattini F, Chrisman J, Nordqvist M (2016b) Family governance at work: organizing for new product development in family SMEs. Fam Bus Rev 29(2):189-213

De Massis A, Audretsch D, Uhlaner L, Kammerlander N (2017) Innovation with limited resources: management lessons from the German Mittelstand. J Prod Innov Manag 35(1):125-146

De Massis A, Frattini F, Majocchi A, Piscitello L (2018) Family firms in the global economy: toward a deeper understanding of internationalization determinants, processes, and outcomes. Glob Strateg J 8(1):3-21

Diaz-Moriana V, Clinton E, Kammerlander N, Lumpkin GT, Craig JB (2018) Innovation motives in family firms: a transgenerational view. Entrep Theory Pract 44(2):256-287

Diéguez-Soto J, Manzaneque M, Rojo-Ramírez A (2016) Technological innovation inputs, outputs, and performance: the moderating role of family involvement in management. Fam Bus Rev 29(3):327-346

Dunn B (1996) Family enterprises in the UK: a special sector? Fam Bus Rev 9:139-155

Duran P, Kammerlander N, Van Essen M, Zellweger T (2016) Doing more with less: innovation input and output in family firms. Acad Manag J 59(4):1224-1264

Dyer G (2003) The family: the missing variable in organizational research. Entrep Theory Pract 27(4):401-416

Eddleston K, Kellermanns F, Ravi S (2008) Resource configuration in family firms: linking resources, strategic planning and technological opportunities to performance. J Manag Stud 45(1):26-50

Eisenhardt K, Martin J (2000) Dynamic capabilities: what are they? Strateg Manag J 21:1105-1121

Eppler M, Hoffmann F, Bresciani S (2011) New business models through collaborative idea generation. Int J Innov Manag 15(06):1323-1341

Filser M, Brem A, Gast J, Kraus A, Calabró A (2016) Innovation in family firms-examining the inventory and mapping the path. Int J Innov Manag 20(6):1650054 
Foss N, Saebi T (2017) Fifteen years of research on business model innovation: how far have we come, and where should we go? J Manag 43(1):200-227

Gatrell C, Breslin D (2017) Editors' statement. Int J Manag Rev 19:1-3

Gómez-Mejía L, Nuñez-Nickel M, Gutierrez I (2001) The role of family ties in agency contracts. Acad Manag J 44(1):81-95. https://doi.org/10.2307/3069338

Gómez-Mejía L, Haynes K, Núñez-Nickel M, Jacobson K, Moyano-Fuentes J (2007) Socioemotional wealth and business risks in family-controlled firms: evidence from Spanish olive oil mills. Adm Sci Q 52(1):106-137

Gomez-Mejia L, Campbell J, Martin G, Hoskisson R, Makri M, Sirmon D (2014) Socioemotional wealth as a mixed gamble: revisiting family firm R\&D investments with the behavioral agency model. Entrep Theory Pract 38(6):1351-1374

Habbershon T, Williams M (1999) A resource-based framework for assessing the strategic advantages of family firms. Fam Bus Rev 12(1):1-25

Harzing AW (2007) Publish or perish. Available from https://harzing.com/resources/publish-or-perish

Hauck J, Prügl R (2015) Innovation activities during intra-family leadership succession in family firms: an empirical study from a socioemotional wealth perspective. J Fam Bus Strat 6:104-118

Heider AK, Gerken M, van Dinther N, Hülsbeck M (2021) Business model innovation through dynamic capabilities in small and medium enterprises-evidence from the German Mittelstand. J Bus Res 130:635-645

Hiebl M (2015) Family involvement and organizational ambidexterity in later-generation family businesses: a framework for further investigation. Manag Decis 53(5):1061-1082

Hillebrand S, Teichert T, Steeger J (2020) Innovation in family firms: an agency and resource-based lens on contingencies of generation and management diversity. Br J Manag 31:792-810

Hoffmann J, Hoelscher M, Sorenson R (2006) Achieving sustained competitive advantage: a family capital theory. Fam Bus Rev 19(2):135-145

Hoon C, Baluch AM (2020) The role of dialectical interrogation in review studies: theorizing from what we see rather than what we have already seen. J Manag Stud 57(6):1246-1271

Hu Q, Hughes M (2020) Radical innovation in family firms: a systematic analysis and research agenda. Int J Entrep Behav Res 26(6):1199-1234

Johann MS, Block JH, Benz L (2021) Financial performance of hidden champions: evidence from German manufacturing firms. Small Bus Econ 1-20

Johnson MW, Christensen CM, Kagermann H (2008) Reinventing your business model. Harv Bus Rev 86(12):57-68

Kammerlander N, Ganter M (2015) An attention-based view of family firm adaptation to discontinuous technological change: exploring the role of family CEOs' noneconomic goals. J Prod Innov Manag 32(3):361-383

König A, Kammerlander N, Enders A (2013) The family innovator's dilemma: how family influence affects the adoption of discontinuous technologies by incumbent firms. Acad Manag Rev 38(3):418-441

Kotlar J, Fang H, De Massis A, Frattini F (2014) Profitability goals, control goals, and the R\&D investment decisions of family and nonfamily firms. J Prod Innov Manag 31(6):1128-1145

Kotlar J, De Massis A, Wright M, Frattini F (2018) Organizational goals: antecedents, formation processes and implications for firm behavior and performance. Int J Manag Rev 20(1):3-18

Kraiczy N, Hack A (2016) Innovation and family business research: a review and future directions. In: Kellermanns F, Hoy F (eds) The Routledge companion to family business. Routledge, New York, pp 211-240

Kraiczy N, Hack A, Kellermanns F (2014) New product portfolio performance in family firms. J Bus Res 67(6):1065-1073

Kraiczy N, Hack A, Kellermanns F (2015) What makes a family firm innovative? CEO risk-taking propensity and the organizational context of family firms. J Prod Innov Manag 32(3):334-348

Llach J, Nordqvist M (2010) Innovation in family and non-family businesses: a resource perspective. Int J Entrep Ventur 2(3-4):381-399

Lodh S, Nandy M, Chen J (2014) Innovation and family ownership: empirical evidence from India. Corp Gov Int Rev 22(1):4-23

March J (1991) Exploration and exploitation in organizational learning. Organ Sci 2(1):71-87

Matzler K, Veider V, Hautz J, Stadler C (2015) The impact of family ownership, management, and governance on innovation. J Prod Innov Manag 32(3):319-333 
Miller D, Wright M, LeBreton-Miller I, Louise S (2015) Resources and innovation in family businesses: the Janus-face of family socioemotional preferences. Calif Manag Rev 58(1):20-40

Munari F, Oriani R, Sobrero M (2010) The effects of owner identoty and external governance systems on R\&D investments: a study of Western European firms. Res Policy 39(8):1093-1104

Muñoz-Bullón F, Sanchez-Bueno M (2011) The impact of family involvement on the R\&D intensity of publicly traded firms. Fam Bus Rev 24(1):62-70

Nieto M, Santamaria L, Fernandez Z (2015) Understanding the innovation behavior of family firms. J Small Bus Manag 53(2):382-399

O'Reilly C, Tushman M (2004) The ambidextrous organization. Harv Bus Rev 82(4):74

Padilla-Meléndez A, Dieguez-Soto J, Garrido-Moreno A (2015) Empirical research on innovation in family business: literature review and proposal of an integrative framework. Revista Brasileira De Gestão De Negócios 17(56):1064-1089

Patel P, Fiet J (2011) Knowledge combination and the potential advantages of family firms in searching for opportunities. Entrep Theory Pract 35(6):1179-1197

Penrose E (1959) The theory of the growth of the firm. John Wiley, New York

Pittino D, Visintin F, Bau M, Mazzurana P (2013) Collabortive technology strategies and innovtion in family firms. Int J Entrep Innov Manag 17:8-27

Post C, Sarala R, Gatrell C, Prescott JF (2020) Advancing theory with review articles. J Manag Stud 57(2):351-376

Pucci T, Brumana M, Minola T, Zanni L (2020) Social capital and innovation in a life science cluster: the role of proximity and family involvement. J Technol Transf 45(1):205-227

Ray G, Barney J, Muhanna W (2004) Capabilities, business processes, and competitive advantage: choosing the dependent variable in empirical tests of the resource-based view. Strateg Manag J 25(1):23-37

Röd I (2016) Disentangling the family firm's innovation process: a systematic review. J Fam Bus Strateg 7(3):185-201

Roessl D, Kraus S, Fink M (2010) Are family firms fit for innovation? Towards an agenda for empirical research. Int J Entrep Ventur 2:366-380

Rondi E, De Massis A, Kotlar J (2019) Unlocking innovation potential: a typology of family business innovation postures and the critical role of the family system. J Fam Bus Strateg 10(4):100236

Rondi E, Überbacher R, von Schlenk-Barnsdorf L, De Massis A, Huelsbeck M (2021) One for all, all for one: a mutual gains perspective on HRM and innovation management practices in family firms. J Fam Bus Strateg. Forthcoming

Rothaermel FT, Hess AM (2007) Building dynamic capabilities: innovation driven by individual-, firm-, and network-level effects. Organ Sci 18:898-921

Salvato C, Melin L (2008) Creating value across generations in family-controlled businesses: the role of family social capital. Fam Bus Rev 21(3):259-276

Sanchez-Famoso V, Maseda A, Iturralde T (2014) The role of internal social capital in organisational innovation. an empirical study of family firms. Eur Manag J 32:950-962

Sanchez-Famoso V, Pittino D, Chirico F, Maseda A, Iturralde T (2019) Social capital and innovation in family firms. The moderating roles of family control and generational involvement. Scand J Manag 35(3):101043

Sanchez-Ruiz P, Daspit JJ, Holt DT, Rutherford W (2019) Family social capital in the family firm: a taxonomic classification, relationships with outcomes, and directions for advancement. Fam Bus Rev 32(2):131-153

Schmid T, Achleitner A-K, Ampenberger M, Kaserer C (2014) Family firms and R\&D behaviournew evidence from a large-scale survey. Res Policy 43(1):233-244

Sciascia S, Nordqvist M, Mazzola P, De Massis A (2015) Family ownership and R\&D intensity in small-and medium-sized firms. J Prod Innov Manag 32(3):349-360

Serrano-Bedia AM, López-Fernández M, Garcia-Piqueres G (2016) Analysis of the relationship between sources of knowledge and innovation performance in family firms. Innovation 18:489-512

Sharma P, Salvato C (2011) Commentary: exploiting and exploring new opportunities over life cycle stages of family firms. Entrep Theory Pract 35(6):1199-1205

Sirmon D, Hitt M (2003) Managing resources: linking unique resources, management, and wealth creation in family firms. Entrep Theory Pract 27(4):339-358

Sirmon D, Hitt M, Ireland D (2007) Managing firm resources in dynamic environments to create value: looking inside the black box. Acad Manag Rev 32(1):273-292 
Sirmon D, Hitt M, Ireland, \& Gilbert. (2011) Resource orchestration to create competitive advantage: breadth, depth, and life cycle effects. J Manag 37(5):1390-1412

Snyder H (2019) Literature review as a research methodology: an overview and guidelines. J Bus Res 104:333-339

Spriggs M, Yu A, Deeds D, Sorenson R (2013) Too many cooks in the kitchen: innovative capacity, collaborative network orientation, and performance in small family businesses. Fam Bus Rev 26(1):32-50

Teece D, Linden G (2017) Business models, value capture, and the digital enterprise. J Organ Des $6(1): 8$

Torraco RJ (2005) Writing integrative literature reviews: guidelines and examples. Hum Resour Dev Rev 4(3):356-367

Torraco RJ (2016) Writing integrative literature reviews: using the past to explore the future. Hum Resour Dev Rev 15:404-428

Tranfield D, Denyer D, Smart P (2003) Towards a methodology for developing evidence-informed management knowledge by means of systematic review. Br J Manag 14:207-222

Tushman M, O'Reilly C (1996) Ambidextrous organizations: managing evolutionary and revolutionary change. Calif Manag Rev 38(4):8-29

Urbinati A, Franzò S, De Massis A, Frattini F (2017) Innovation in family firms: a review of prior studies and a framework for future research. In: Brem A, Viardot E (eds) Revolution of innovation management. Palgrave Macmillan, London, pp 213-246

Webster J, Watson RT (2002) Analyzing the past to prepare for the future: writing a literature review. MIS Q XIII-XXIII

Weimann V, Gerken M, Hülsbeck M (2020) Business model innovation in family firms: dynamic capabilities and the moderating role of socioemotional wealth. J Bus Econ 90(3):369-399

Weimann V, Gerken M, Hülsbeck M (2021) Old flames never die-the role of binding social ties for corporate entrepreneurship in family firms. Int Entrep Manag J 17:1707-1730

Wernerfelt B (1984) A resource-based view of the firm. Strateg Manag J 5(2):171-180

Zahra S, Hayton J, Salvato C (2004) Entrepreneurship in family vs. non-family firms: a resourcebased analysis of the effect of organizational culture. Entrep Theory Pract 28(4):363-381

Zellweger T (2007) Time horizon, costs of equity capital, and generic investment strategies of firms. Fam Bus Rev 20(1):1-15

Zott C, Amit R, Massa L (2011) The business model: recent developments and future research. J Manag 37(4):1019-1042

Publisher's Note Springer Nature remains neutral with regard to jurisdictional claims in published maps and institutional affiliations. 